\title{
Örgütlerde Algılanan Sosyal Destek ve Toksik Duygular ìlişkisi: İyimserlik ve Kötümserliğin Aracılık Etkisi ${ }^{1}$
}

\author{
Arş. Gör. Mehmet Ali TAŞ² - Dr. Öğr. Üyesi Meral BEKTAŞ³
}

\section{Öz}

Örgüt içerisinde zehirleyici duygu durumunu ifade eden toksisitenin, tüm örgütlerde bir noktaya kadar etkisini gösterdiği bilinen bir gerçektir. Olumsuz duyguların yarattı̆̆ı kirli iklim, örgütleri ve çalışanlarını önemli ölçüde olumsuz etkileyebilmektedir. Bu olumsuz havanın çalı̧̧anlarda yarattığı zehirleyici etkinin, algılanan sosyal destek ve iyimserlik gibi faktörler vasıtasıla yumuşaması diğer taraftan kötümserlik faktörü ile artması beklenmektedir. Bu beklentiyi sınamak amacıyla, özel bir çağrı merkezi çalışanlarından anket yöntemiyle veriler toplanmış ve analiz edilerek bulgular sunulmuştur. Elde edilen bulgulara göre değişkenler arasında önemli ve anlamlı ilişkiler tespit edilmiştir. Ayrıca algılanan sosyal desteğin ve toksik duygu durumlarının bazı boyutları arasında gerçekleşen ilişkide, iyimserlik ve kötümserliğin aracılık rolü tespit edilmiştir.

Anahtar Kelimeler: Algılanan Sosyal Destek, Toksik Duygular, L̇yimserlik, Kötümserlik, Aracılık Etkisi

Atıf: Taş, M. A. ve Bektaş, M. (2020). Örgütlerde algılanan sosyal destek ve toksik duygular ilişkisi: İyimserlik ve kötümserliğin aracılık etkisi. Anadolu Üniversitesi Sosyal Bilimler Dergisi, 20(4), 83-106.

\footnotetext{
Bir önceki yıl dergiye yayın başvurusunda bulunulmuş makale olduğundan geriye dönük etik kurul izni gerekmemektedir.

Burdur Mehmet Akif Ersoy Üniversitesi İIBF Sağlık Yönetimi, matas@mehmetakif.edu.tr, ORCID: 0000-0001-9714-7188

3 Burdur Mehmet Akif Ersoy Üniversitesi Sosyal Bilimler Meslek Yüksek Okulu Büro Hizmetleri ve Sekreterlik Bölümü, mbektas@mehmetakif.edu.tr, ORCID: 0000-0002-1616-8065
} 


\title{
The Relationship Between Perceived Social Support and Toxic Emotions in Organizations: The Mediating Role of Optimism and Pessimism
}

\author{
Res. Asst. Mehmet Ali TAŞ - Asst. Prof. Dr. Meral BEKTAŞ
}

Submitted by: 26.06 .2019

Accepted by: 25.11 .2020

Article Type: Research Article

\begin{abstract}
It is a known fact that toxicity, which expresses the toxic state in the organization, has an effect up to some point in all organizations. The polluted climate caused by negative emotions can significantly affect their organizations and employees. It is expected that the toxic effect of this negative atmosphere on employees will be softened by factors such as perceived social support and optimism and to increase with the pessimism factor. In order to test this expectations, data were collected from the employees of a private call center with survey method and the data were, analyzed and were presented. According to the findings, important and significant relationships between the variables were determined. Furthermore, the mediating role of optimism and pessimism in the relationship between perceived social support and some dimensions of toxic emotions was determined.
\end{abstract}

Keywords: Perceived Social Support, Toxic Emotions, Optimism, Pessimism, Mediating Effect 


\section{Giriş}

Doğası gereği insanların sevme, sevilme ve ait olma gibi ihtiyaçları bulunmaktadır. Genellikle insanlar yakın ve samimi ilişkiler kurmak isterler. Çalışma hayatında da bunalan bireyler derdini anlatacakları ve çözüm önerileri ile destek bulacağı doğal kaynaklara sığınmak isterler (Marcinkus, vd., 2007, s. 104). Bu kaynakların başında aile, eş, iş arkadaşları, danışmanlar ve öğretmenler gelmektedir. Ancak insanların her zaman çevrelerindeki bu kaynaklardan olumlu etkilendiği de söylenememektedir. Denge Kuramında (Heider, 1946) insanların çevrelerinden ve çevredeki negatif ve pozitif değişimin sebeplerinden etkilendiği ifade edilmektedir.

Çalışanlar özellikle iş ortamlarında, iş hayatının ve örgütsel yapıdan kaynaklanan bir takım toksik tutum ve davranışlara maruz kalmaktadır (Bektaş ve Erkal, 2015, s. 520). Bu tutum ve davranışların sürekli tekrar etmesi sonucunda çalışanlar bazen izole olmakta, zamanla bezmekte ya da tükenebilmektedir. Bu zehirleyici atmosferi soluyan bazı çalışanlar ise olumsuz durumla karşılaştıklarında bir an önce bu durumdan kurtulma çabasına girmektedirler. Bu çabalardan bir tanesi destek arayışıdır. Nitekim Fredrickson'in (2001) geliştirdiği İnşa Kuramına göre, ilişkileri devam ettirmek ve daha fazlasını elde etmek için sosyal kaynaklar inşa edilmektedir. Böylece olumsuz duygulara karşı destek bulma olasılığı yükselerek pozitif duyguların daha fazla deneyimlenmesi sağlanmaktadır. Çünkü olumsuzluğun boyutu ne olursa olsun çalışanlara sosyal destek sağlandığı takdirde tükenmişlik ve stres düzeyinin düştüğü ifade edilmektedir (Torun, 1995, s. 7). Sosyal desteğin sağlanması durumunda stresin patolojik etkileri azalabilmekte, hatta bazen hastalıkların önünde tampon vazifesi bile görebilmektedir (Chien vd., 2000, s. 69-84). Sosyal destek çalışanlar için saygı, bilgi, sosyal arkadaşlık, duygusal destek, dinlenme, takdir, kabul görme ve meydan okuma gibi anlamlar taşımaktadır (Cohen ve Wills, 1985, s. 310-357).

İş hayatında toksisite ile mücadele noktasında yeterli ve doğru desteği alamayan çalışanlar, örgüt için kaliteli iş çıkarmak adına harcamaları gereken zamanı ve enerjiyi bu toksisite durumlarıyla baş edebilmek için harcamaktadır. Bu durum, çalışanlara ve örgüte olumsuz bir çıktı şeklinde yansıyabilmektedir. Bazen çalışma ortamında toksik duygularla boğuşan çalışanlar gerek yöneticilerinden gerekse iş arkadaşlarından bu durumdan kurtulmak için sosyal destek beklentisine girmektedir. Çünkü sosyal destek bir ihtiyaç olarak algılanmakta ve giderilmeye çalışılmaktadır. Bu noktada iyimserlik düzeyi yüksek olan çalışanların sosyal destekten daha fazla yararlandıkları söylenebilmektedir (Karademas, 2006). Psikolojik olarak dayanıklı ve dirençli bireyler, stres, taciz, aşağılanma, azarlanma, kaygı, tehdit gibi olumsuzluklar silsilesi ile karşılaştıkları durumlarda başarılı bir şekilde kendilerini koruyabilmektedirler. Dirençli kişiler, başa çıma mekanizmalarından biri olan mücadele etmeyi tercih edebilmektedirler. Böyle olumsuzluk sarmalında iyimser olan bireyler bu durumun geçici ve genel olmadığı kanısına varmakta ve kendilerini kısa sürede toparlayabilmektedirler (Peterson ve Bossio, 2001, s. 129).

İncelenen literatür çerçevesinde toksik duyguların çalışanları meşgul ettiği, motivasyonu, verimliliği, etkililiği ve performansı düşürdüğü ve özellikle çalışanları mutsuz ettiği görülmektedir. Bu durumda, mutsuz olan çalışanlardan olağanüstü bir performans beklemek gerçek dışı bir çaba olmaktadır. Çünkü Genişletme Kuramında (Fredrickson, 2001) insanların mutsuz olduklarında düşünme ve yaratıcılık repertuarlarının daraldığı ifade edilmektedir. İzole olmuş, bezmiş ve enerjisi tükenmiş bir çalışan kitlesinin örgüte katkıları olmadığı gibi zararları da dokunabilmektedir. Bu nedenle örgütlerde sosyal ilişkilerin kurulmasına zemin hazırlayan bir örgüt tasarımı gerekmektedir. Zehirli atmosferin dağılmasında ve çalışanların rahatlamasında sosyal desteğin önemli bir etkiye sahip olması beklenmektedir. Bunun yanında ayrıca kişinin sahip olduğu psikolojik bir sermaye olan ve hem kişilik özelliği hem de olayları açılama tarzı olarak da ifade edilen iyimserlik/kötümserliğin toksik duygularla başa çıkmada önemli birer mekanizma olabileceği düşünülmektedir. 
Bu çalışmada, söz konusu değişkenler bir modelde ele alınarak aralarındaki ilişkinin ortaya konulması çalışma açısından önem arz etmektedir. $\mathrm{Bu}$ amaçla yürütülen bu çalışma, stresli çalışma atmosferinde çalışmak durumunda kalan çağrı merkezi çalışanları üzerinde gerçekleştirilmiştir. Bu nedenle, algılanan sosyal desteğin toksik duygular üzerindeki etkisinde iyimserlik/kötümserlik aracı etkisi bir model çerçevesinde analiz edilerek sunulmuştur. Bu değişkenleri bir modelde değerlendirerek aralarındaki ilişkiyi ortaya koyan başka bir çalışmanın olmaması bu çalışmayı özgün kıldığı düşünülmektedir.

\section{Algılanan Sosyal Destek}

İnsanlar arasında bağ kurulmasının önemine yapılan vurgu yüzyıllar öncesine dayanmaktadır. İnsanoğlunun tek başına hayatını sürdürmesi beklenmemektedir. Bu nedenle insanın sağlıklı bir şekilde hayatına devam edebilmesi için diğer insanlarla iletişime geçmesinin gerekli olduğu ileri sürülmektedir. Bireylerin yaptıkları işler ve kazandıkları başarıların sosyal ilişkiler sayesinde olduğu ifade edilmektedir (Stroebe ve Stroebe, 1996; Akt: Sönmezsoy, 2018, s. 4). Her bireyin, ihtiyacı gereği sürekli olarak sosyal kaynaklardan beslenmesi gerekmektedir. Bireyler önemsendiği ve değer gördüğü ölçüde mutlu olmakta ve zorlukların üstesinden gelebilmektedir. Aksi takdirde ruhsal hastalıklar baş gösterebilmektedir (Sorias, 1988). Bu noktada bireyler aile, eş ve arkadaş çevresinin oluşturduğu psikolojik oksijen çadırı sayesinde rahatlayarak kendilerine olumlu bir psikolojik solunum sağlayabilmektedir. Genel olarak bu çevreden beklenen destek ve yardıma da algılanan sosyal destek denilmektedir.

Algılanan sosyal destek, ihtiyaç anında yardım sağlanabileceği inancı veya destek ağları tarafından sağlanan destekleyici davranışları kapsamaktadır. Bu destek genel olarak aileden ve diğer sosyal çevreden beklenmektedir (Barnett vd., 2018, s. 188). Bu bağlamda sosyal destek; bireyin değer verilmesini, önemsenmesini ve bir gruba duygusal açıdan bağlanmasını sağlayan ilişkiler ve etkileşimler bütünüdür (Pugliesi ve Shook, 1998, s. 216; Akın, 2015, s. 48). Bir durum veya ilişki hakkındaki belirsizliği azaltarak kişinin rahatlamasına zemin hazırlayan sözlü ve sözsüz iletişimdir (Collins vd., 2016, s. 162). Bu iletişim ise alıcının iyi oluşunu yükseltmeye yöneliktir (Shumaker ve Brownell, 1984, s. 13). Bu nedenle sosyal destek aslında önemli bir başa çıkma yöntemi ve stresle mücadele mekanizmasıdır (Usta, 2015, s. 80). Bunun yanında bir benlik saygısı ve aitlik gibi önemli ihtiyaçları karşılayan bir sağlık düzenleyicisidir (Polat ve Kahraman, 2013, s. 214).

Sosyal destek daha çok bireyin çevresinden algıladığı desteğe odaklanmaktadır. Bu destek paketi içerisinde aile, özel kişiler ve iş arkadaşları bulunmaktadır (Kirmeyer ve Lin, 1987, s. 148). Bu nedenle sosyal destek kavramının iş hayatını da kapsadığı ileri sürülmektedir (Polatcı, 2015, s. 28). Çalışanların işyerinde birbirlerine sağladıkları sosyal desteğin, performansları üzerinde önemli bir etkisinin olabileceği ifade edilmektedir. Öyle ki iş arkadaşları, bir meslektaşının ne yapması gerektiği (ne yapmaması gerektiği) konusundaki inançlarını şekillendirmeye yardım ederek, onu cesaretlendirme noktasında ona önemli bazı davranışsal destek sağlamaktadır (Chiaburu ve Harrison, 2008, s. 1085). Bu nedenle işyerinde sosyal destek, kişinin kapasitesini zorlamasına ve başarılı olmasına zemin hazırlamaktadır. Bu deneyimlerden dolayı da bireyin refah düzeyini olumlu şekilde etkilemektedir (Collins vd., 2016, s. 162).

Genel itibariyle sosyal desteğin olumlu etkisinden bahsedilse de aslında beklenmeyen durumlara da yol açması ihtimal dâhilindedir. Çünkü sosyal desteğin alıcıda nasıl bir reaksiyona yol açtığı konusunda net bir açıklama getirilememiştir. Bu bağlamda her zaman iyi oluşu olumlu etkileyen bir unsur olduğunu söylemek doğru olmasa gerek (Gray, 2018, s. 3). Sosyal destek, bireyin rol belirsizliğini, rol çatışmasını ve iş yükünü azaltabilir ve bu da iş tatmini ve örgütsel bağlllı̆̆ yükseltebilmektedir. Buna karşın iş yerinde olumsuz örgüt iklimi ve arzu edilmeyen ilişkiler çalışanlarda stres ve iş memnuniyetsizliğine neden olabilmektedir. Bu durum çalışanın mutluluğunu olumsuz etkileyebilmektedir. İşyerinde saygısız, güvensiz ve istismarcı gibi sosyal ilişkiler, toksik bir örgüt iklimine sebep olmaktadır (Oksanen vd., 2010, s. 686-687 ). Örgütte yaşanan iletişim ve duygusal 
desteğin azlığı yüksek maliyetlere sebep olabilmektedir. Nitekim çalışanların işten ayrılma niyetlerinin artmasına ve bunun da ötesinde iş gücü devir oranın yükselmesine neden olabilmektedir (Chiaburu ve Harrison, 2008, s. 1085).

Sosyal destek genel olarak kişinin özel ve iş hayatını etkilemektedir. Nitekim bu algı Malow’un ihtiyaçlar hiyerarşisinin üçüncü basamağında yer almaktadır. Sosyal destek hem beklenti hem ihtiyaçtır. Bu ihtiyacın giderilmesiyle bir üst basamağa geçilebileceği ifade edilmektedir. sosyal destek algısının gerçekleşmesi durumunda performans, motivasyon, bağlllık ve iş tatmini artmakta (Marcinkus, vd., 2007, s. 104) diğer yandan tükenmişlik, kaygı, stres gibi unsurlarda azalmaktadır (Lindorff, 2001, s. 281; Bhaunthumnavian, 2003, s. 80; Clara, vd., 2003, s. 265; Daalen, vd., 2006, s. 464-465). Bu nedenle sosyal desteğin aslında bireye birçok açıdan katkı sağladığı ifade edilebilir (Polatcı, 2015, s. 28). Ek olarak, sosyal destek depresyon ve anksiyete gibi duygu durumlarında etkili bir rol oynayabilir ve stresin etkilerini hafifletme gücüne sahip olabilir (Lim vd., 2010, s. 28; Barnett vd., 2018, s. 188). Bu nedenle sosyal destek bir koruma ve geliştirme mekanizması olduğu söylenebilir (Polat ve Kahraman, 2013, s. 217).

\section{İyimserlik ve Kötümserlik}

Pozitif psikolojide irdelenen ve insanların dünyaya ve olaylara neden ve nasıl iyimser bakabildiklerine dair yapılan çalışmalardan bazıları, kişinin geleceğe pozitif bakabilmesi ve olumsuz olayları dış çevreye bağlamasıyla ilgili olan iyimserlik ile ilgilidir (Carr, 2016, s. 108-109; Youssef ve Luthans, 2007, s. 779; Carr, 2016, s. 107).

1970’li yılların sonuna kadar iyimserlik karakter zayıfllğı ve psikolojik bir eksiklik olarak değerlendirilmiştir. Bireyin geleceği dengeli ve duygulardan arındırılmış bir şekilde değerlendirme gücünü, zihinsel sağılığını ve yetişkinliğini ortaya koyan bir gösterge şeklinde bakılmaktaydı (Peterson, 2000, s. 44-47; Carr, 2016, s. 107). Sonraki yıllarda yapılan çalışmaların birçoğunda insanların düşünce yapılarında iyimser sürecin daha yoğun olduğu bulgusuna ulaşılmıştır. Buna göre birçok insan olumlu şeyleri olumsuzlardan daha fazla hatırladığı tespit edilmiştir. Kişiler, hayatın her alanında iyimser tavırlarını daha fazla ortaya koyduğu keşfedilmiştir (Norem, 2001, s. 93).

İyimserlik kavramı; iyi oluş, sağlık, verimlilik ve başarı gibi unsurlarla ilişkisinden dolayı bireye güç veren bir yapı olarak tanımlanmaktadır. İyimserlik olumsuz olayların inkârı değildir. Ancak dirençli ve mutlu bireylerin bir özelliği olduğu ileri sürülmektedir. Diğer taraftan iyimserliğin gerçekçi, esnek ve makul olması önem arz etmektedir. Yoksa kör iyimserliğin, bireylerin psikolojik ve fiziksel sağlıkları üzerinde olumsuz bir etkiye sahip olduğu bilinmektedir (Hefferon ve Boniwell, 2011, s. 95).

İyimserlik ile kötümserlik ayrımı, insanların beklentileri üzerinde temellendirildiği görülmektedir. Olumlu gelecek bekleyenlere iyimser tersini bekleyenlere ise kötümser denilmektedir (Türkmenoğlu, 2017, s. 120). Hatta iyimserliğin insanın ruh sağlığının olumlu tarafını, kötümserliğin ise patolojik tarafını temsil ettiği ileri sürülmektedir (Eryılmaz, 2015, s. 390). Burada bahsedilen iyimserlik kavramı iki ana yaklaşımla değerlendirildiği görülmektedir. Birincisi kişinin genel olumlu beklentileri ile nitelenen bir kişilik özelliği (Çalışkan ve Uzunkol, 2018, s. 79) iken ikincisinde ise olayları açılama tarzı şeklinde değerlendirilmektedir (Peterson ve Bossio, 2001, s. 129; Seligman, 1998; Youssef ve Luthans, 2007, s. 778; Hefferon ve Boniwell, 2011, s. 95; Türkmenoğlu, 2017, s. 120). Kişilik özeliği olarak ifade edilen iyimserlik yaklaşımında, bireyler gelecekte olumsuzluktan ziyade olumlu yöne odaklanmakta ve gelecek için belirledikleri hedeflere ulaşma noktasındaki beklentileri iyimser yöndedir. Bu durum kişilerin amaçları çerçevesinde hareket ettiğini ileri süren amaçbeklenti kuramına atıf yaptığı görülmektedir. Diğer taraftan yükleme tarzı olarak ifade edilen iyimserlikte bireyler, meydana gelen olumsuz olayları dışsal (benim hatam değil), geçici (bu yalnızca şimdi oldu) ve spesifik (yalnızca bu olay) olarak görürken; kötümser kişiler ise tam tersi bir tutum sergilemektedir. Kötümserler 
olumsuz olayları içsel (benim hatam), kalıcı (bu her zaman oluyor) ve genel (her olay) şeklinde yorumladıkları görülmektedir (Hefferon ve Boniwell, 2011, s. 96; Peterson, 2000, s. 48; Karacaoğlu ve İnce, 2013, s. 185). Kötümserler başarısızlığı iç dünyalarına bağlamaktadır. Başarısızlık ve talihsizliklerinin devam edeceğine inanmaktadırlar. Geçmişin sorunlarına atıf yaparak olumsuz düşüncenin içinden çıkmakta zorlanırlar. Geleceğe yönelmediklerinden dolayı başarısız olmakta ve ilerleme kaydedememektedirler (Toor ve Ofori, 2010, s. 342; Avey vd., 2008, s. 54).

Kötümser kişilik özelliğine sahip kişilerde durumu inkâr etme yaklaşımı aracıllı̆ıyla başa çıkma davranışından kaçınması söz konusudur. Bu noktada kötümserlik, olumsuz olayları dış çevreye bağlayarak kadere atıf yaptığı ifade edilmektedir (Carr, 2016, s. 115). İyimser bireyler, olumsuz durumlar karşısında etkili başa çlkma ile kendilerini ve motivasyonlarını korumaktadır. Böylece amaçlarına daha rahat ilerledikleri görülmektedir. Kötümser kişiler ise her koşulda en kötü senaryoyu beklediği ifade edilmektedir (Eryılmaz, 2015, s. 390; Çalışkan ve Uzunkol, 2018, s. 79).

İyimserlik ve kötümserlik unsurlarının her ikisi de bir kişide aynı anda bulunabileceği ileri sürülmektedir. Birinin varlığında diğerinin ortaya çıkması söz konusu olmaktadır. Bu durumun olayları açıklama tarzıyla yakından ilişkili olduğu ifade edilmektedir. Olumsuz olay veya zehirleyici bir çevrede insanların kötümser ancak olumlu ve rahat bir çevrede ise iyimser olabileceği ileri sürülmektedir. Yani depresyon, kaygı, stres, hastalık, baskı ve mobbing gibi durumların varlığında kötümserlik yokluğunda ise iyimserliğin olacağı ifade edilmektedir. $\mathrm{Bu}$ nedenle hangisi daha fazla beslenirse ve ortaya çıkmasına yardımcı olunursa kişi onu davranışlarına ve hayatına yansıtmaktadır (Peterson, 2000, s. 44-50).

\section{Toksik Duygular}

Toksik kavramı genel olarak zararl, zehirli ve ölümcül olan (Chu, 2014, s. 954), solunum yoluyla teneffüs edilen zehirli bir madde olarak ifade edilmektedir (Bektaş ve Erkal, 2015, s. 520). Duygu ise çevresel olayların etkilerine karşı uyarılma işlevi görmektedir. Bu uyarılma için enerji ve uygun eylemi başlatma güdüsü sağlamaktadır (Spector ve Fox, 2002, s. 272). Bu bağlamda toksik duygular, çalışanın olumsuz (öfke ve hayal kırıklığı), tekrarlanan, tüketen (duygusal yorgunluk) ve tefrik eden (izolasyon) davranışlarını betimlemektedir (Kiefer ve Barclay, 2012, s. 601). İş yerinde toksik duygular, çalışanların güçlü enerji tüketicileri olarak tanımlanmaktadır (Frost, 2003, s. 5; Akt: Kasalak ve Aksu, 2016, s. 677). Burada bahsedilen toksik duygular, olumsuz duygularla veya mobbingle karıştırılmamalıdır. Olumsuz duygular genel olarak kısa süreli, yoğun olmakta ve kişiyi eyleme geçmesine odaklamaktadır ( Parkinson, 1995, s. 9). Mobbing ise belli bir kişiyi hedef alarak sistematik bir saldırı yapılırken toksik duyguların belli bir sistemi bulunmamaktadır. $O$ anda o ortamda bulunanlar etkilenmektedir (Kasalak ve Aksu, 2016, s. 677). Toksik duygular uzun süreli ve tekrar etme özelliğine sahiptir. Ancak olumsuz duyguların zamanla toksik duygulara dönüşebileceği ifade edilmektedir (Kiefer ve Barclay, 2012, s. 603).

Toksik duyguların önemli üç özelliği bulunmaktadır. Bu özellikler aynı zamanda toksik duygu deneyimleri ölçeğinin boyutlarını oluşturmaktadır. Bunlardan ilki tekrar eden duygulardır. Bu duygular, bireye duygusal ağırlık yükleyen, çözülmediği duygusu veren ve tekrarlanması beklenilen duygulardır. Toksik duygular tekrar ettikçe bireye duygusal ve psikolojik bir yorgunluk yüklemektedir. İkincisi Bağlantıyı kesen duygulardır. Bunlar daha çok sosyal ağa vurgu yapmaktadır. Bireyin sosyal ağından ve iş arkadaşlarından ayrılmasını ifade etmektedir. İzolasyon ve zayıf aidiyet hissi yaratmaktadır. Üçüncüsü de bezdirici duygulardır. Bezdirici duygular bireyi bilişsel ve fiziksel olarak tükenme aşamasına getirmektedir. Bu duygular kişiyi anında etkilemekte ve o anda birey tükenmişlik ve enerji kaybı yaşamaktadır (Kiefer ve Barclay, 2012, s. 603-604; Chu, 2014, s. 954; Bektaş ve Erkal, 2015, s. 522). 
Örgütlerde toksik duygulara sebep olan yedi kaynaktan bahsedilmektedir (Frost, 2004, s. 112-115; Bektaş ve Erkal, 2015, s. 520). Bunlar:

1. Yöneticinin zorbaca davranışlarından ve bilerek isteyerek itaat ettirme, acı çektirme ve çalışanların özgüvenin baltalama aruzundan kaynaklanan kötü niyet.

2. Yöneticinin yetersizliği ve kontrol düşkünlüğü nedeniyle çalışanlara baskı yapması, sonucunda ise çalışanların stres yaşamasına sebep olan yetersiz beceriye sahip yöneticiler.

3. Yöneticilerin gerektiği durumlarda çalışanlarını savunmaması ve terfi zamanlarında onları desteklememesi sonucunda örgütte ihanet havasının yayılmasına sebep olan yönetici sadakatsizliği.

4. Duygusal zeka düzeyi düşük olan çalışanların/yöneticilerin empati yönü düşük ve duygusal belirsizliği olması durumu olan duyarsizlik.

5. Özellikle karizmatik liderler çalışanlarını başarı odaklı çalıştırmaktadır. Aşırı iş yüküne maruz kalan çalışanlar iş ve özel hayat dengesi de zarar görmektedir. Lider bir gün başarısız olduğunda veya işi bıraktığında lidere olan aşırı bağlılıktan dolayı çalışanların hayal kırıklığına uğraması durumu olan ihlal.

6. Sistematik etik dışı davranışları, imkânsız hedefleri, sürekli ücretten kesintileri, sürekli politika değişikliklerini ifade eden kurumsal güçler.

7. Kaçınılmayan duygusal acılar, travmatik etkiler, teknolojik değişimler ve yetersiz kalan yetenekler gibi kaçınılmazlık olduğu ifade edilmektedir.

Yönetici davranışları, örgütün refah ve olumlu iklimi için önemli derecede etkilidir (Bowling ve Michel 2011, s. 309). Çünkü toksik kaynakların başlıca sebebi aslında toksik yöneticilikten gelmektedir. Art niyetli denetimler, bilerek astlara hakaret etmek, üzmek ve özgüvenden yoksun bırakmak, alay etmek, küçük düşürmek ve sindirmek arzusu gibi başlıca yönetici davranışlar toksik hava yaratmaktadır. Bu davranışlar etik dışı, saldırgan, narsist ve katı olduğu ifade edilmektedir (Kasalak ve Aksu, 2016, s. 687). Toksik duygu ve davranışların örgüt içerisinde devam etmesinin önemli bir diğer sebebi de toksik duyguları yayan çalışanların olmasıdır. Bu çalışanların; koruyucu özel bağlantılara ve güçlere sahip olması, kritik bir işin başında olması veya yüksek düzeyde yetenekli ve önemli bir boşluğu dolduruyor olması toksik davranışların tekrarlanmasına sebep olabilmektedir (Kusy ve Holloway, 2010, s. 145-146; Bektaş ve Erkal, 2015, s. 521).

Haksız yere olumsuz muameleye maruz kalan çalışanların sosyal mübadele teorisine göre karşılık vermesi beklenmektedir. Çalışanlar tutumlarını değiştirecekleri ve bozulan adaleti sağlamaya çalışacakları ileri sürülmektedir (Tepper vd., 2009, s. 157; Chu, 2014, s. 954). Bunlardan bir tanesi de kasıtlı olarak yapılan üretim karşıtı davranışlardır. Bu davranışlar saldırganlık, sapma, misilleme ve intikam gibi çeşitli eylemlerden oluşmaktadır (Spector ve Fox 2002, s. 274, Bowling ve Michel 2011, s. 309; Wei ve Si 2013, s. 283). Ancak duygusal toksisitenin örgütsel yaşamın bir yan ürünü olduğunun kabul edilmesi gerekmektedir. Etkili yönetilmesi sonucunda zararları minimize edilebilmektedir (Frost, 2004, s. 111). Aksi takdirde çalışanları rahatsız eden zorbalıkların ve katlanmak zorunda oldukları toksik davranışların zararlı sonuçları hem çalınanları hem de örgütü tehdit etmektedir (Kiefer ve Barclay, 2012, s. 600; Chu, 2014, s. 953).

Görüldüğü üzere toksik duygular ile tutum ve davranışlar yüksek düzeyde ilişkilidir (Kiefer ve Barclay, 2012, s. 602). Kurumlar bu toksik duyguları etkin şekilde yönetemez ise çalışanlarından verim alması zorlaşacaktır. Çünkü toksik duyguların önemli bir diğer kaynağı da iş arkadaşları olabilmektedir (Kasalak ve Aksu, 2016, s. 677). Bu nedenle örgüt içerisinde yönetilmeyen toksisitenin, çalışanların öz yeterliliklerini, umutlarını, iyimserliklerini, morallerini dolayısıyla motivasyonlarını, performanslarını ve dayanıklılık düzeylerini düşürmesi beklenmektedir (Wei ve Si 2013, s. 283). Çalışanların mesajlarına cevap verilmediğinde, önemsenmedikleri ve değer görülmedikleri durumlarda, nezaket ve etik dışı davranışlar karşısında duygusal 
anlamda zehirlendikleri ifade edilmektedir. Çalışanlar işten ve örgütten kopma hali yaşamaya başlamaktadır. Yaşadıkları acıya odaklanmakta bu nedenle duygusal ve entelektüel enerjilerini iş süreçlerinde kullanamamaktadırlar (Frost, 2004, s. 11).

\section{Algılanan Sosyal Destek, Toksik Duygular, İyimserlik ve Kötümserlik ilişkisi}

Pozitif duyguların olumsuz ruh halini aşmak için bir kaynak olduğu ve önemli başa çıkma stilleriyle ilişkili olduğu ileri sürülmektedir (Tugade vd., 2004, s. 1163). Genişletme teorisinin öngördügü gibi, sık sık olumlu duyguları deneyimleyen bireyler, yalnızca zevk aldıkları için değil, geniş bir yaşamın zorluklarıyla başa çıkmaya yardımcı olan kaynaklar oluşturdukları için daha tatmin olmaktadır (Cohn vd., 2009, s. 362). Dahası esnek bireyler yalnızca kendilerinde olumlu duygular geliştirmekle kalmaz, aynı zamanda yakın sosyal çevrelerini de olumlu duygu sarmalına çekmektedir. Yani sosyal çevre bireyin, birey de sosyal çevrenin iyi oluşu deneyimlemesinde rol oynamaktadır. Genişletme ve inşa teorisinin perspektifinden bakıldığında, pozitif duygular bireysel gelişim ve sosyal destek için önemli araçlar olduğu görülecektir. İnsanların kişisel ve sosyal kaynaklarını inşa ederek, pozitif duygular açısından daha iyi hale gelmekte ve gelecekte daha iyi hayat sürmektedir (Fredrickson, 2001, s. 220-223).

Her ne kadar olumlu duygular olumlu bir örgüt iklimi yaratsa da olumsuz duygular da iş ortamına yayılarak diğer çalışanları zehirlemektedir. Çalışanlar arasında sosyal ilişkilerin önem verildiği günümüzde iletişim kanalları vasıtasıyla örgütsel düzeyde bir zehirlenmenin söz konusu olabileceği ileri sürülmektedir. Bu durum toksik örgüt kültürünün oluşmasına zemin hazırlamaktadır (Bektaş ve Erkal, 2015, s. 520). Toksik örgüt kültüründe çalışanların sosyal destek alması daha az zehirlenmesine yol açmaktadır. Nitekim psikolojik sorunlarla sosyal desteğin negatif bir ilişkisinin olduğu saptanmıştır (Akın, 2015, s. 49). Olumsuz durumlarla mücadele etme, kararlılıkla direnebilme ve sıkıntılarla başa çıkma stratejisinin en popüler ve faydalı şekli meslektaşlardan, aileden ve arkadaşlardan sosyal destek sağlamaktır (Lim vd., 2010, s. 30). Bir başka çalışmada da sosyal çevrenin bireye sağladığı destekler bireyin benlik saygılarını ve direncini olumlu etkilediğini ortaya koymuştur (Arıc1, 2015, s. 152). Buradan hareketle algılanan sosyal desteğin, bireylerin zorluklar karşısındaki duruşunu sağlamlaştırması, direnmesi, harekete geçerek mücadele etmesi ve bu mücadelede kararlı ve dayanıklı olması noktasında önemli bir rol oynayacağı söylenebilir. Bu bağlamda algılanan sosyal desteğin iyi oluş yükselterek toksik havayı nispeten dağıtacağı ve insanların rahatlamalarına yardımcı olacağı düşünülerek H1 hipotezi geliştirilmiştir.

\section{H1: Algılanan sosyal destek, toksik duygu durumların etkilemektedir.}

Örgüt içerisinde beslenen olumlu sosyal ilişkiler çalışanların üretkenlik, zenginlik ve öğrenme kaynağını oluşturmaktadır. Pozitif ilişkiler insanlara mutluluk ve uzun yaşam sağlamaktadır. Güçlenen sosyal ilişkilerin insan davranışlarını düzenlediği bilinmektedir. İnsanlar desteklendikleri, sevildikleri ve manevi destek aldıklarında kendilerini değerli ve güvende hissedebilmektedir. Sonucunda geleceğe ilişkin iyimserlik düzeyinin arttığı ve performansın yükseldiği tespit edilmiştir (Cameron, 2013, s. 51-56). Kötümser kişilerin mücadeleyi hızlı şekilde bıraktıkları ve olayın akışına teslim oldukları (Seligman, 2006, s. 5) görülmüştür. Ancak iyimserliğin kişiyi sempatik yaparak sosyal destek alma ihtimalini arttırabilmektedir (Karademas, 2006). Sosyal destek kişilerin olumsuz hayat deneyimlerinin ve stresörlerinin etkisini azaltarak iyi oluşlarını ve gelecek beklentilerini olumlu şekilde etkileyebilmektedir (Pugliesi ve Shook, 1998, s. 216-217). Sosyal destek uyumu arttırması nedeniyle kötümser havayı dağıtmakta ve sosyal ilişkilerin kurulmasını kolaylaştırmaktadır (Akın, 2015, s. 48). Bu açılamalar 1şı̆̆ında H2 ve H3 geliştirilmiştir.

H2: Algilanan sosyal destek, iyimserliği etkilemektedir.

H3: Algilanan sosyal destek, kötümserliği etkilemektedir. 
İyimser olan insanlar diğer insanlara veya çalışma arkadaşlarına da olumlu davranmakta ve saygı çerçevesinde ilişkiler geliştirmektedir. İyimserliği bir kişilik özelliği olarak açıklayan teoriler bu durumun okul öncesi çağdan başlayıp ölünceye kadar devem ettiğini ifade etmektedir. İyimser olan insanların geleceği olumlu şekilde düşünmesi sonucunda olayların seyrini kendilerinin değiştirebileceğine inanmaktadır. İçsel kontrol algısına sahip oldukları görülmektedir. Bu nedenle hem daha fazla çalışmaya motive olmakta hem de olumsuz bir durum karşısında işlerine odaklanmaktadır. İyimser kişiler dayanıklılık düzeyleri yüksek olup, kararlı ve performanslı çalışmaktadır (Carr, 2016, s. 112). Uzun vadeli planlar yapar ve örgütün neden olacağı toksik iklime karşı dirençli oldukları ifade edilmektedir (Hefferon ve Boniwell, 2011, s. 102). İyimser bireylerin kötümserlere nazaran daha olumsuz koşullarda çalışabildiği saptanmıştır. Olumsuz durumlar karşısında aktif başa çıkma yöntemini kullanarak sosyal destek ararken kötümserler ise pasif başa çıkma yönetimini tercih edip kaçınmacı davranmakta ve içe kapanmaktadır (Hefferon ve Boniwell, 2011, s. 98).

İyimserlik zor zamanlarda sıkıntılarla baş edebilmek için etkili bir rol oynamaktadır. Bireyler, her koşulda hedefe ilerleme kararlılığı göstermekte ve sorunların derinliklerinde kaybolmamaktadır. Diğer taraftan kötümser kişiler, öz yeterlilik ve güven noktasında problem yaşamakta ve atacakları adımlar konusunda tereddütte düşmektedirler (Çalışkan ve Uzunkol, 2018, s. 79). Bu nedenle bu çalışmada iyimserliğin toksik bir örgütte çalışanların toksik duygu düzeylerini düşüreceği düşünülmektedir. Dolayısıyla H4 ve H5 hipotezi geliştirilmiştir.

H4: İyimserlik, toksik duygu durumların etkilemektedir.

H5: Kötümserlik, toksik duygu durumlarını etkilemektedir.

$\mathrm{Bu}$ çalışmada değişken olarak değerlendirilen algılanan sosyal destek, toksik duygular, iyimserlik ve kötümserlik arasındaki ilişkinin bir modelle gösterilmesi amaçlanmaktadır. Bu modelde algılanan sosyal destek bağımsız, toksik duygular bağımlı, iyimserlik ve kötümserlik ise aracı değişken olarak belirlenmiştir. İkili modelle yapılmış çalışmaların sonuçlarında yukarıda bahsedildiği gibi değişkenler arasında belli bir ilişkinin olduğu görülmektedir (Tugade vd., 2004, Carr, 2016, Wei ve Si 2013; Frost, 2004; Cohn vd., 2009; Lim vd., 2010; Karademas, 2006; Akın, 2015; Pugliesi ve Shook, 1998; Cameron, 2013; Peterson, 2000; Youssef ve Luthans, 2007; Çalışkan ve Uzunkol, 2018; Hefferon ve Boniwell, 2011). Nitekim çeşitli şekillerde kavramsallaştırılan ve değerlendirilen iyimserlik, olumlu ruh hali ve iyi bir moralle ilişkilendirilmektedir. Ancak iyi oluş üzerinde çevrenin etkisi büyüktür. Güçlü sosyal ilişkiler, olumlu bakış açısı kişiye güç ve enerji sağalmaktadır. Kişi çevresel destekten mahrum kalırsa kötümserlik düzeyi artmakta ve tehditlere karş1 korunmasız olmaktadır (Peterson, 2000, s. 44-50). Bu açıklamalar ışı̆̆ında, söz konusu dört değişken birlikte değerlendirilerek bir model tasarlanmış (Bkz. Şekil 1) ve H6 hipotezi geliştirilmiştir.

H6: Algılanan sosyal desteğin toksik duygular üzerindeki etkisinde iyimserlik ve kötümserlik değișkenleri aracı rol oynamaktadir.

\section{Araştırmanın Metodolojisi}

Araştırmanın bu aşamasında; araştırmanın modeli, örneklemi, veri toplama araçları, veri analizinde kullanılan yöntemler ve araştırmanın bulguları yer almaktadır.

Araştırmanın hipotezleri doğrultusunda oluşturulan araştırmanın modeli şekil 1'de gösterilmiştir. Buna göre Algılanan Sosyal Destek ve Toksik Duygu Deneyimleri ilişkisinde iyimserlik ve kötümserliğin aracı rol oynaması beklenmektedir. 


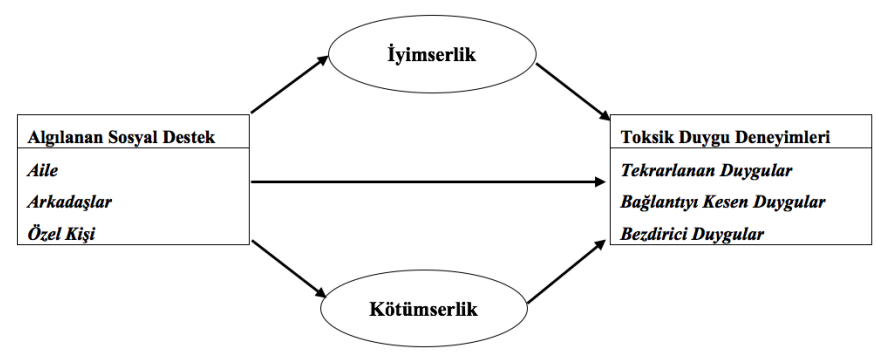

Şekil 1. Araştırmanın Modeli

\section{Araştırmanın Örneklemi}

$\mathrm{Bu}$ araştırma, yaklaşık olarak 300 kişinin çalıştığı özel bir çağrı merkezinde yapılmıştır. Araştırmada 200 anket dağıtılmış ancak bu anketlerden 178 tanesinin eksiksiz doldurulduğu görülmüştür. Buna göre dağıtılan anketlerin cevaplanma oran $1 \% 89$ olduğu tespit edilmiştir. Elde edilen bu veri seti analize tabi tutularak, analiz için gerekli işlemlerden geçirilirken uç değer teşkil eden anketin bulunmaması nedeniyle tüm anketler analize dâhil edilmiştir.

Örneklem kitlesinden veri toplamak için anket formu kullanılmış olup anket formunda da üç farklı ölçek yer almaktadır. Bunlar: "Algılanan Sosyal Destek Ölçeği (ASDÖ)", "Toksik Duygu Deneyimleri Ölçeği (TDDÖ)” ve "İyimserlik/Kötümserlik Ölçeği (İKÖ)"”dir.

\section{Veri Toplama Araçları}

Algılanan Sosyal Destek Ölçeği (ASDÖ): Zimet ve meslektaşları (1988) tarafından geliştirilen Algılanan Sosyal Destek Ölçeği 3 boyut ve 12 maddeden oluşmaktadır. Buna göre ölçeğin boyutları: aile 4 madde, arkadaşlar 4 madde ve özel kişi 4 madde şeklinde belirlenmiştir. Bu ölçek 5) Tamamen katılıyorum ve 1) Hiç katılmıyorum şeklinde 5'li likert tipi ile derecelendirilmiştir. Ölçeğin geçerlilik ve güvenirlik çalışması Eker ve Arkar (1995) tarafından gerçekleştirilmiş olup Türk kültüründe uygulanabileceği kanıtlanmıştır.

Toksik Duygu Deneyimleri Ölçeği (TDDÖ): Keifer ve Barclay (2012) tarafından geliştirilen bu ölçekte tekrarlanan duygular (tekduy) 5 madde, bağlantıyı kesen duygular (bağkes) 5 madde ve bezdirici (yorucu) duygular (bezduy) 4 madde olmak üzere 3 boyut ve 14 maddeden oluşmaktadır. Ölçekte 5) Tamamen katılıyorum ve 1) Hiç katılmıyorum şeklinde 5'li likert tipi derecelendirme kullanılmıştır. Ölçeğin Türkçeye uyarlama çalışması ise Bektaş ve Erkal (2015) tarafından yapılmış, geçerliliği ve güvenirliği sınanmıştır. Sonuçta bu ölçeğin Türk kültürüne uygulanabilen güvenilir bir ölçme aracı olduğu tespit edilmiştir.

İyimserlik/Kötümserlik Ölçeği (İKÖ): Çalışkan ve Uzunkol (2018) tarafından geliştirilen bu ölçek, iyimserlik 8 madde ve kötümserlik 8 madde olmak üzere 2 boyut ve 16 maddeden oluşmaktadır. Bu ölçekte 5) Tamamen katılıyorum ve 1) Hiç katılmıyorum şeklinde olmak üzere 5'li likert tipi bir derecelendirme kullanılmıştır.

\section{Birinci Düzey Doğrulayıcı Faktör Analizi Bulguları}

Kullanılan ölçek maddelerinin faktör yüklerini sınamak ve maddelerin özgün formlarda olduğu gibi dağılım gösterip göstermediğini ortaya koymak amacıyla DFA Lisrel 8.8 programı kullanılarak Doğrulayıcı Faktör Analiz (DFA) yapılmıştır. Elde edilen uyum iyiliği değerleri tablo 1'de gösterilmiştir. Bu tabloda olması gereken normal değerler, kabul edilebilir asgari değerler (Aksu vd., 2017, s. 79; Papatya vd., 2016, s. 32; Kocagöz ve Dursun, 2010, s. 145) ve ikinci düzey DFA değerleri yer almaktadır.

İlk olarak Algılanan Sosyal Destek Ölçeği analize tabi tutulmuştur. Analiz sonucunda maddelerin özgün formda olduğu gibi dağılım gösterdiği tespit edilmiştir. Yanı sıra uyum iyiliği değerlerinin olduğu çıktı dosyası incelenerek gerekli modifikasyon işlemleri yapılmıştır. Mevcut kuramsal gerekçeler de dikkate alınarak modele en fazla katkıyı sağlayacak işlemler uygulanmıştır. Buna göre aile3 ile aile4 ve özel2 ile özel4 maddeleri birbirine 
bağlanmıştır. Ayrıca, gerekli faktör yükünü vermemesi ve uyum iyiliği değerlerini düşürmesi gerekçesiyle aile3 maddesi modelin dışında bırakılmıştır. Toksik Duygu Deneyimleri Ölçeği ile ilgili yapılan işlemler incelendiğinde, uyum iyiliği değerlerini düşürmesi ve hata varyanslarının yüksek olması nedeniyle tekduy5, bağkes5 ve bezduy4 maddeleri modele dâhil edilmemiştir. İyimserlik/Kötümserlik Ölçeğine ilişkin yapılan DFA sonucunda ise iyi1 ile iyi2, iyi5 ile iyi15, iyi7 ile iyi13, kötü4 ile kötü12 ve kötü6 ile kötü16 maddeleri arasında modifikasyon işlemi yapılarak birbirine bağlanmıştır. İlaveten kötü2 maddesi modelden çıkarılmıştır.

Ölçeklere ilişkin tespit edilen ve tablo 1'de verilen bu değerler, oluşturulan DFA modellerinin anlamlı ve kabul edilebilir düzeyde olduğunu göstermektedir.

\section{İkinci Düzey Doğrulayıcı Faktör Analizi Bulguları}

İkinci düzey DFA yapılmasının temel amacı Toksik Duygu Deneyimleri ve Algılanan Sosyal Destek Ölçeklerinin alt boyutlarının bir araya gelmesi sonucunda oluşturacakları sinerjiyi ortaya koymaktır. Bu nedenle ilgili ölçeklerin boyutları, bir üst yapı olarak tanımlanan “ASDÖ” ve “TDDÖ” örtük değişkenlerine ne ölçüde uyum sağladıkları ikinci düzey DFA ile tespit edilmeye çalışılmıştır. Elde edilen uyum iyiliği değerleri tablo 1'de gösterilmiştir.

Algılanan Sosyal Destek Ölçeği için ikinci düzey DFA uygulanırken bazı modifikasyonlar yapılmıştır. Arkadaş2 ile arkadaş3 maddeleri arasında modifikasyon işlemi uygulanarak birbirine bağlanmıştır. Aile3 maddesi ise uyum iyiliği değerlerini düşürmesi nedeniyle modele dâhil edilmemiştir. Bunun yanında elde edilen tüm $t$ değerlerini anlamlı olduğu tespit edilmiştir $(\mathrm{t}>1.96 ; \mathrm{p}<.05)$. Dört boyutlu modele ilişkin faktör yükleri incelendiğinde (Standardized Solution) ise aile 99. ile 1.00, arkadaş 92. ile 1.00 ve özel 1.03 ile 1.11 arasında değiştiği tespit edilmiştir. Elde edilen bu değerler modelin iyi uyum gösterdiğini ve ilgili boyutların" ASDÖ” örtük değişkenini anlamlı şekilde yordadığını göstermektedir. Bu nedenle Algılanan Sosyal Destek Ölçeğinin üç faktörlü yapısının anlamlı olduğu söylenebilir.

Toksik Duygu Deneyimleri Ölçeğine ilişkin yapılan ikinci düzey DFA neticesinde çıktı dosyası incelenmiştir. Sunulan öneriler gereği tekduy5, bağkes5 ve bezduy4 maddeleri modelden çıkarılmıştır. Bu işlemler sonucunda elde edilen uyum iyiliği değerleri tablo 1'de sunulmuştur. Bu değerler incelendiğinde Toksik Duygu Deneyimleri Ölçeğine ilişkin üç faktörlü ölçek yapısının anlamlı olduğu tespit edilmiştir. Söz gelimi tekrar eden duygular boyutunun bu modele olan faktör yükü 1.12 ile 1.23, bağlantıyı kesen duygular 1.09 ile 1.23 ve bezdirici duygular ise 0.91 ile 1.20 arasında değiştiği tespit edilmiştir. Bunun yanında t değerlerinin de anlamlı çlkması ( $\mathrm{t}>1.96$; $\mathrm{p}<.05)$ neticesinde boyutların örtük değiş̧ken olarak belirlenen "TDDÖ”ni anlamlı şekilde yordadıkları söylenebilir.

Tablo 1

Birinci ve İkinci Düzey DFA Uygunluk Değerleri ve Ölçeklerin Aldığı Değerler Tablosu

\begin{tabular}{|c|c|c|c|c|c|c|c|}
\hline \multirow[b]{2}{*}{ İndeksler } & \multirow[b]{2}{*}{ Normal Değerler } & \multirow[b]{2}{*}{$\begin{array}{l}\text { Kabul Edilebilir } \\
\text { Değerler }\end{array}$} & \multicolumn{3}{|c|}{ Birinci Düzey DFA } & \multicolumn{2}{|c|}{ İkinci Düzey DFA } \\
\hline & & & ASDÖ & TDDÖ & İKÖ & ASDÖ & TDDÖ \\
\hline$\chi^{2 / s d}$ & $0 \leq \chi^{2} / \mathrm{sd} \leq 3$ & $3 \leq \chi^{2 / s d} \leq 5$ & 1,94 & 2,24 & 1,66 & 1,98 & 2.24 \\
\hline GFI & $.95 \leq \mathrm{GFI} \leq 1.00$ & $.90 \leq \mathrm{GFI} \leq .95$ & 0.93 & 0.93 & 0.90 & 0.92 & 0.91 \\
\hline AGFI & $.90 \leq \mathrm{AGFI} \leq 1.00$ & $.85 \leq \mathrm{AGFI} \leq .90$ & 0.88 & 0.89 & 0.86 & 0.88 & 0.86 \\
\hline CFI & $.95 \leq \mathrm{CFI} \leq 1.00$ & $.90 \leq \mathrm{CFI} \leq .95$ & 0.98 & 0.97 & 0.98 & 0.98 & 0.98 \\
\hline NFI & $.95 \leq \mathrm{NFI} \leq 1.00$ & $.90 \leq \mathrm{NFI} \leq .95$ & 0.97 & 0.96 & 0.96 & 0.96 & 0.97 \\
\hline RMSEA & $.00 \leq \mathrm{RMSEA} \leq .05$ & $.05 \leq \mathrm{RMSEA} \leq .010$ & 0.073 & 0.084 & 0.061 & 0.075 & 0.084 \\
\hline $\begin{array}{l}p-\text { value< } \\
\text { ASDÖ: Al\& } \\
\text { TDDÖ: To } \\
\text { İKÖ: İyim }\end{array}$ & $\begin{array}{l}1 \\
\text { anan Sosyal Destek } \\
\text { sik Duygu Deneyiml } \\
\text { rlik/Kötümserlik Ölç }\end{array}$ & $\begin{array}{l}\text { ceği } \\
\text { Ölçeği }\end{array}$ & & & & & \\
\hline
\end{tabular}


Analizlere geçmeden önce DFA analizleri sonucunda belirlenen boyutların analize uygunluk kriterini sağlayıp sağlamadığını ortaya koymak amacıyla normal dağılımı test edilmiştir. Tüm ölçeklerin ve ilgili boyutlarının normal dağılım değerlerinin (skewness/kurtosis) - 1 ve +1 arasında (Gürbüz ve Şahin, 2015, s. 208-210) olduğu tespit edilmiştir. Buna göre veri seti ortalama etrafında dağılım gösterdiği söylenebilir. Bunun yanında örneklemin analiz için yeterliliğini saptamak amacıyla Kaiser-Meyer-Olkin (KMO) testi uygulanmıştır (İslamoğlu ve Alnıaçı, 2014, s. 403). Buna göre İKÖ ve ASDÖ çok iyi ve TDDÖ ise mükemmel değerler arasında olduğu tespit edilmiştir (Bkz. Tablo 4). Ardından ilgili değişkenlerin Cronbach’s Alpha güvenirliği test edilerek elde edilen bulgular tablo 4'te gösterilmiştir.

\section{Araştırmanın Bulguları}

Betimsel analiz sonucunda katılımcıların sosyo-demografik özellikleri ile ilgili elde edilen bulgular tablo 2'de gösterilmiştir.

Tablo 2

Katılımcıların Sosyo-Demografik Özellikleri

\begin{tabular}{|c|c|c|c|c|c|c|c|}
\hline & \multicolumn{3}{|c|}{ Ö̈rneklemin Dağılımı } & & \multicolumn{3}{|c|}{ P̈̈rneklemin Dağılımı } \\
\hline & & $\mathrm{N}$ & $\%$ & & & $\mathrm{~N}$ & $\%$ \\
\hline \multirow{2}{*}{ Cinsiyet Dağılımı } & Kadın & 132 & 74,2 & \multirow{3}{*}{$\begin{array}{l}\text { Hizmet } \\
\text { Süreleri (Yıl) }\end{array}$} & $1-5$ & 136 & 79.5 \\
\hline & Erkek & 46 & 25.8 & & $6-10$ & 29 & 17 \\
\hline \multirow{3}{*}{ Yaş Dağılımı } & 25 ve alt1 & 109 & 61.9 & & $11+$ & 6 & 3.5 \\
\hline & $26-35$ & 62 & 35.2 & & & & \\
\hline & $36+$ & 5 & 2.9 & & & & \\
\hline \multirow{2}{*}{ Medeni Durumu Dağılımı } & Evli & 24 & 14 & & & & \\
\hline & Bekâr & 147 & 86 & & & & \\
\hline
\end{tabular}

Bu çalışmaya dâhil edilen katılımcıların 132'si (\%74.2) kadınlardan oluşmaktadır. 147'si (\%86) ise bekâr olduğu tespit edilmiştir. Katılımcıların 109'u (\%61.9) 25 ve altındaki yaş grubunda yer almaktadır. Bunun yanında hizmet süreleri bağlamında katılımcılar incelendiğinde 1-5 yıl çalışan kişi sayısı 136 (\%79.5) olduğu saptanmıştır. Buna göre katılımcıların profili incelendiğinde büyük çoğunluğu kadın, bekâr, 25 ve altı yaş aralığında ve 1-5 yıl aralığında çalışma süresine sahip olduğu görülmektedir.

\section{Fark Testi Bulguları}

Demografik bulguların yanı sıra cinsiyet ayrımı bağlamında ölçeklerin ilgili boyutları düzeylerinde anlamlı bir farklılı̆̆ın olup olmadığını sınamak amacıyla Independent Sample T testi uygulanmıştır. Buna göre cinsiyet farklılı̆̆ bağlamında ölçeklerin ve ilgili boyutlarının ortalamalarında anlamlı bir farklılığa rastlanmamıştır ( $>$ >.05). Bu nedenle bu bulguyla ilgili tablo verilmemiştir. Ancak medeni durum değişkeni bağlamında ölçeklerin ortalamalarında anlamlı farklılıklar tespit edilmiştir. Elde edilen bulgular tablo 3'de gösterilmiştir.

Tablo 2'de verilen bulgulara göre katılımcıların; TDDÖ $\left(\mathrm{t}_{(169)}=.2 .20 ; \mathrm{p}<.05\right)$, Tekduy $\left(\mathrm{t}_{(169)}=-2.09 ; \mathrm{p}<.05\right)$ ve Aile $\left(\mathrm{t}_{(169)}=2.02 ; \mathrm{p}<.05\right)$ değişkenlerine ilişkin ortalamalarında anlamlı ve önemli bir farklılı̆̆ın olduğu görülmektedir. Analiz sonucunda elde edilen ortalamalara göre TDDÖ ve Tekduy değişkenlerinde bekâr katılımcıların ortalamaları evli katılımcılarınkinden daha yüksek olduğu tespit edilmiştir. Bunun yanında aile desteği boyutunda ise evli katılımcıların ortalaması daha yüksek olduğu saptanmıştır ( $<<.05)$. 
Tablo 3

Medeni Durum Bağlamında Kullanılan Ölçeklerin Boyutlarına İlişkin Fark Analizi Tablosu

\begin{tabular}{lllllllll}
\hline \hline & Evli & \multicolumn{7}{c}{ Bekâr } \\
\cline { 2 - 9 } & Ort. & S.S. & Ort. & S.S. & $\mathrm{p}$ & $\mathrm{t}$ & $\mathrm{f}$ & Anlamlı Fark \\
\hline TDDÖ & 1.82 & 1.00 & 2.26 & .95 & .037 & -2.20 & .338 & Bekâr> Evli \\
Tekduy & 1.93 & 1.23 & 2.50 & 1.23 & .038 & -2.09 & .002 & Bekâr> Evli \\
Aile & 4.38 & .56 & 4.11 & .87 & .050 & 2.02 & .017 & Evli> Bekâr \\
\hline D.f. (Serbestlik Derecesi)= & 169 & & & & & & \\
TDDÖ: Toksik Duygu Deneyimleri Ölçeği & & & & & & \\
Tekduy: Tekrarlanan Duygular & & & & & & & \\
\hline \hline
\end{tabular}

$\mathrm{Bu}$ analizlerin yanında ayrıca yaş grupları ve çalışma süreleri bağlamında değişkenlerin ortalamaları arasında anlamlı farklılığın olup olmadığı test edilmiştir. Bu analiz ANOVA testi ile gerçekleştirilmiştir. Elde edilen bulgular ise tablo 4’te gösterilmiştir. Tüm değişkenlerin güvenirlik değerlerinin yüksek olduğu görülmektedir.

Tablo 4

Katılımcıların Yaş Grupları Bağlamında Ölçeklerin Boyutlarına İlişkin Fark Analizi Bulguları Tablosu

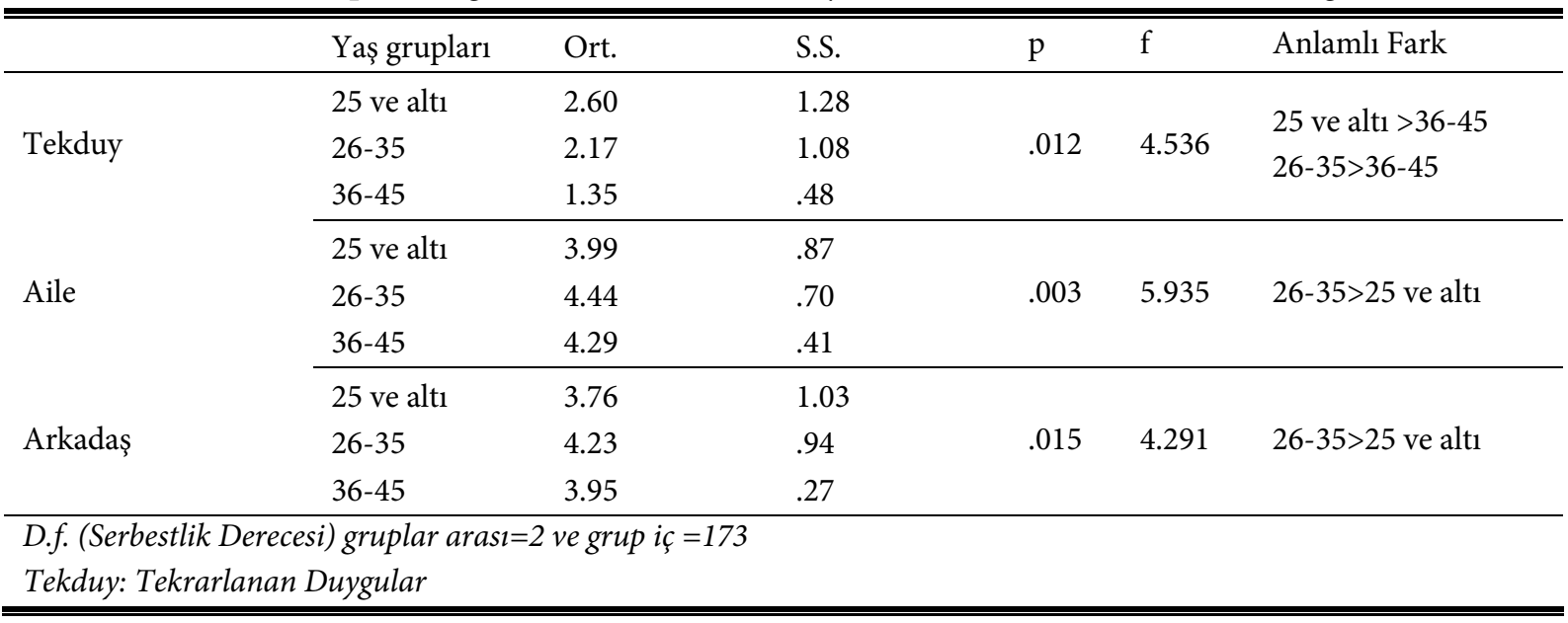

Elde edilen analiz bulguları incelendiğinde farklı yaş gruplarında yer alan katılımcıların Tekduy $\left(\mathrm{F}_{(2.173)}=4.536\right.$; $\mathrm{p}<.05)$, Aile $\left(\mathrm{F}_{(2.173)}=5.935 ; \mathrm{p}<.05\right)$ ve Arkadaş $\left(\mathrm{F}_{(2.173)}=4.291 ; \mathrm{p}<.05\right)$ değişkenlerine ilişkin görüşlerinde anlaml bir farklılığa rastlanmıştır. Bu bulgular neticesinde ortalamalar incelendiğinde tekduy boyutunda hem 25 ve altı hem de 26-35 yaş grubunun ortalamaları, 36-45 yaş grubunun ortalamasından daha yüksek olduğu saptanmıştır $(\mathrm{p}<.05)$. Aile ve arkadaş destekleri boyutlarının her ikisinde de 26-35 yaş grubunun ortalaması 25 ve altı yaş grubunun ortalamasından daha yüksek olduğu tespit edilmiştir $(\mathrm{p}<.05)$.

Ancak çalışma süreleri bağlamında değişkenlerin ortalamaları arasında anlamlı bir farklılığa rastlanmamıştır ( $\mathrm{p}>$.05). Bu nedenle bu bulguyla ilgili tablo verilmemiştir.

\section{Korelasyon Testi Bulguları}

Değişkenler arasında ilişkinin olup olmadığını test etmek amacıyla korelasyon analizi uygulanmıştır. Burada ilişkinin yönü ve şiddeti belirlenmektedir. Elde edilen buldular tablo 5 ’te gösterilmiştir. 
Tablo 5

Ölçekler Arasındaki İlişki, Ölçeklerin Ortalamaları ve Güvenirlik Değerleri Tablosu

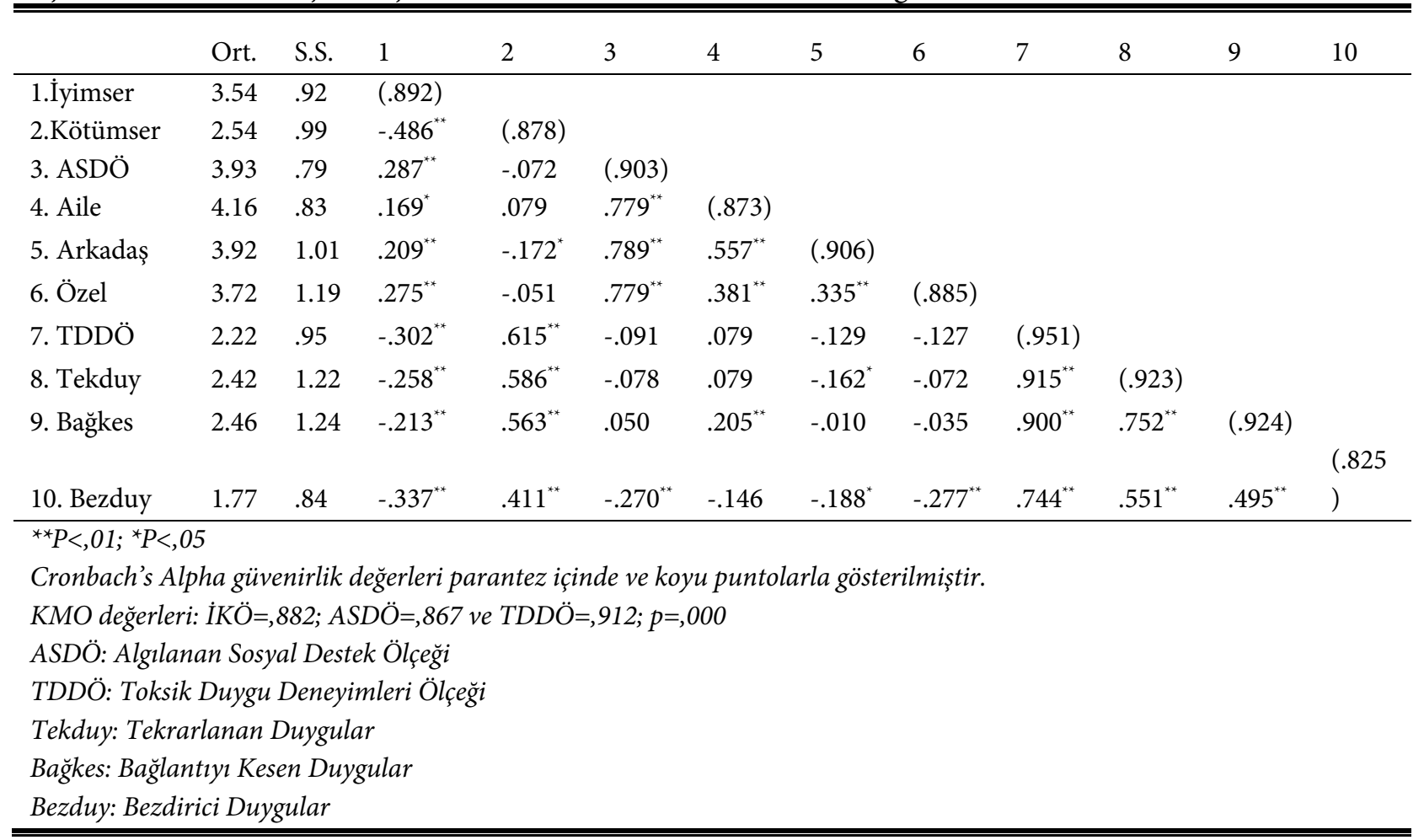

Tablo 5 incelendiğinde en yüksek ortalama sahip değişkenin aile boyutu (ort.=4.16; S.S.=83) olduğu görülmektedir. Bezduy ise en düşük ortalamaya sahip boyut olduğu saptanmıştır (ort.=1.77; S.S.=84).

İyimserlik boyutunun ASDÖ ve ilgili boyutlarılla pozitif fakat TDDÖ ve ilgili boyutlarıyla negatif ve anlamlı ilişkisinin olduğu tespit edilmiştir $(\mathrm{p}<.05)$. Kötümserlik boyutu ise arkadaş boyutuyla negatif ancak toksik duygu deneyimleri ve ilgili tüm boyutlarıyla pozitif ve anlamlı ilişkisinin olduğu saptanmıştır (p<.05). ASDÖ ile bezduy negatif, aile boyutu ile bağkes pozitif, arkadaş boyutu ile tekduy ve bezduy boyutları arasında negatif ve son olarak da özel boyutu ise sadece bezduy ile arasında anlamlı ve negatif yönlü bir ilişkisinin olduğu tespit edilmiştir $(\mathrm{p}<.05)$.

\section{Regresyon Testi Bulguları}

Bağımsız değişken olarak belirlenen ölçek ve faktörlerin bağımlı değişkenler üzerindeki etkisini sınamak amacıyla doğrusal regresyon analizi uygulanmıştır. Elde edilen bulgular tablo 6,7, 8 ve 9 da gösterilmiştir. 
Tablo 6

Sosyal Desteğin Toksik Duygu Deneyimleri Üzerindeki Etkisine İlişkin Regresyon Testi Bulguları

\begin{tabular}{|c|c|c|c|c|c|c|c|c|c|}
\hline \multirow{2}{*}{$\begin{array}{l}\text { BAĞIMSIZ } \\
\text { DEĞİŞKENLER }\end{array}$} & \multicolumn{9}{|c|}{$\begin{array}{l}\text { BAĞIMLI DEĞİŞKENLER } \\
\text { TDDÖ }\end{array}$} \\
\hline & $\beta$ & \multicolumn{2}{|c|}{ S.H. } & $p$ & \multicolumn{5}{|c|}{ Regresyon Modelin Özeti } \\
\hline \multirow[t]{3}{*}{ ASDÖ } & -.124 & \multicolumn{2}{|c|}{.091} & .099 & \multicolumn{5}{|c|}{$\mathrm{R}^{2}=.015 ;$ Adj. $\mathrm{R}^{2}=.010 ; \mathrm{F}=2.752 ; \mathrm{p}=.099$} \\
\hline & \multicolumn{3}{|c|}{ Tekduy } & \multicolumn{3}{|l|}{ Bağkes } & \multicolumn{3}{|c|}{ Bezduy } \\
\hline & $\beta$ & S.H. & $p$ & $\beta$ & S.H. & $p$ & $\beta$ & S.H. & $p$ \\
\hline Aile & ,054 & ,117 & ,600 & ,134 & 119 & 194 &,- 064 & , 108 & ,524 \\
\hline Arkadaş &,- 186 & ,119 & 060 &,- 074 &, 121 & ,455 &,- 011 & , 110 & ,908 \\
\hline Özel &,- 032 & ,085 & ,702 &,- 067 & ,086 & ,426 &,- 198 & ,078 &, 016 \\
\hline $\begin{array}{l}\text { Regresyon Modelin } \\
\text { Özeti }\end{array}$ & \multicolumn{3}{|c|}{$\mathrm{R}^{2}=.028 ;$ Adj. $\mathrm{R}^{2}=.011$} & \multicolumn{3}{|c|}{$\mathrm{R}^{2}=.011 ;$ Adj. $\mathrm{R}^{2}=-.006$} & \multicolumn{2}{|c|}{$\mathrm{R}^{2}=.056 ;$ Adj. $\mathrm{R}^{2}=.040$} & $\mathrm{~F}=3.469 ; \mathrm{p}=.017$ \\
\hline $\begin{array}{l}\text { ASDÖ: Algilanan So } \\
\text { TDDÖ: Toksik Duyg } \\
\text { Tekduy: Tekrarlanar } \\
\text { Bağkes: Bağlantıyı K } \\
\text { Bezduy: Bezdirici Du }\end{array}$ & $\begin{array}{l}\text { Pestek } \\
\text { neyimle } \\
\text { gular } \\
\text { Duygul } \\
\text { ar }\end{array}$ & $\begin{array}{l}\breve{g} i \\
l \operatorname{lçeği} i\end{array}$ & & & & & & & \\
\hline
\end{tabular}

Tablo 6'da verilen bulgular incelendiğinde ASDÖ ve TDDÖ değişkenleri arasında kurulan regresyon modelinin anlamlı olmadığı görülmektedir ( $\mathrm{p}>.05)$. Dolayısıyla $\mathrm{H} 1$ reddedilmiştir. Bunun yanında algılanan sosyal desteğin boyutlarıyla ile toksik duygu durumlarının tekduy ve bağkes boyutlarıla kurulan regresyon modelleri de anlamlı olmadığ 1 ( $>$.05), fakat bezduy boyutuyla kurulan modelin anlamlı olduğu saptanmıştır $(\mathrm{p}<.05)$. Buna göre sadece özel boyutunun bezduy boyutunu anlamlı ve negatif etkilediği saptanmıştır $(\beta=-$ $, 198 ; \mathrm{p}<0.05)$.

Tablo 7

Sosyal Desteğin İyimserlik/Kötümserlik Üzerindeki Etkisine İlişkin Regresyon Testi Bulguları

\begin{tabular}{|c|c|c|c|c|c|c|}
\hline \multirow{3}{*}{ BAĞIMSIZ DEĞİŞKENLER } & \multicolumn{6}{|c|}{ BAĞIMLI DEĞİŞKENLER } \\
\hline & \multicolumn{3}{|c|}{ İYIMMSERLİK } & \multicolumn{3}{|c|}{ KÖTÜMSERLİK } \\
\hline & $\beta$ & S.H. & $p$ & $\beta$ & S.H. & $p$ \\
\hline ASDÖ & .325 & .075 & .000 & -.119 & .085 & .113 \\
\hline \multirow[t]{3}{*}{ Regresyon Modelin Özeti } & \multicolumn{3}{|c|}{$\begin{array}{l}\mathrm{R}^{2}=.106 ; \text { Adj. } \mathrm{R}^{2}=.101 ; \mathrm{F}=20.837 \\
p=.000\end{array}$} & \multicolumn{3}{|c|}{$\mathrm{R}^{2}=.014 ;$ Adj. $\mathrm{R}^{2}=.009 ; \mathrm{F}=2.536 ; p=.113$} \\
\hline & \multicolumn{3}{|c|}{ İYİMSERLİK } & \multicolumn{3}{|c|}{ KÖTÜMSERLİK } \\
\hline & $\beta$ & S.H. & $p$ & $\beta$ & S.H. & $p$ \\
\hline Aile & ,205 & ,084 & ,037 & ,071 & ,094 & ,484 \\
\hline Arkadaş & 015 & ,085 & ,872 &,- 215 & ,096 & ,029 \\
\hline Özel & , 184 & ,061 & ,021 &,- 009 & ,068 & ,913 \\
\hline Regresyon Modelin Özeti & \multicolumn{3}{|c|}{$\mathrm{R}^{2}=.114 ;$ Adj. $\mathrm{R}^{2}=.099 ; \mathrm{F}=7.447 ; p=.000$} & \multicolumn{3}{|c|}{$\mathrm{R}^{2}=.033 ;$ Adj. $\mathrm{R}^{2}=.016 ; \mathrm{F}=1.950 ; p=.123$} \\
\hline ASDÖ: Algılanan Sosyal Dest & $c ̧ e \breve{g} i$ & & & & & \\
\hline
\end{tabular}

Tablo 7'de gösterilen bulgulara göre ASDÖ sadece İyimserlik ile kurulan regresyon modelinin istatistiksel olarak anlamlı olduğu saptanmıştır ( $\mathrm{p}=.000)$. Buna göre bağımsız değişken olarak belirlenen ASDÖ’nün iyimserliği $(\beta=.325 ; \mathrm{p}<0.05)$ olumlu ve anlamlı şekilde yordadığ tespit edilmiş olup, H2 kabul edilmiştir. 
Bunun yanında boyutlar bağlamında kurulan regresyon modelleri incelendiğinde ( $\mathrm{p}=.000)$; özel ( $\beta=.184$; $\mathrm{p}<0.05)$ ve aile $(\beta=.205 ; \mathrm{p}<0.05)$ boyutlarının iyimserliği olumlu ve anlamlı şekilde etkilediği tespit edilmiştir. Ancak ASDÖ’nün kötümserliği anlamlı şekilde yordamadığı görülmüştür ( $p>.05)$. Bu nedenle H3 reddedilmiştir. Diğer yandan sosyal desteğin boyutlarından sadece arkadaş boyutunun kötümserliği anlamlı ve negatif yönde etkilediği tespit edilmiştir $(\beta=-.215 ; p<0.05)$.

Tablo 8

İyimserliğin Toksik Duygu Deneyimleri Üzerindeki Etkisine İlişkin Regresyon Testi Bulguları

\begin{tabular}{|c|c|c|c|c|c|c|c|c|c|c|}
\hline \multirow{2}{*}{$\begin{array}{l}\text { BAĞIMSIZ } \\
\text { DEĞİŞKENLER }\end{array}$} & \multicolumn{10}{|c|}{$\begin{array}{l}\text { BAĞIMLI DEĞİŞKENLER } \\
\text { TDDÖ }\end{array}$} \\
\hline & $\beta$ & \multicolumn{2}{|c|}{ S.H. } & \multicolumn{2}{|l|}{$p$} & \multicolumn{5}{|c|}{ Regresyon Modelin Özeti } \\
\hline \multirow[t]{3}{*}{ İYİMSERLİK } & -.298 & .08 & & .000 & & \multicolumn{5}{|c|}{$\mathrm{R}^{2}=, 089 ; \operatorname{Adj} \cdot \mathrm{R}^{2}=, 084 ; \mathrm{F}=17.169 ; p=, 000$} \\
\hline & \multicolumn{3}{|c|}{ Tekduy } & \multicolumn{3}{|c|}{ Bağkes } & & \multicolumn{2}{|c|}{ Bezduy } & \\
\hline & $\beta$ & S.H. & $p$ & & $\beta$ & S.H. & $p$ & $\beta$ & S.H. & $p$ \\
\hline İYİMSERLİK & -.258 & .097 & .001 & & -.213 & .099 & .004 & -.332 & .089 & .000 \\
\hline $\begin{array}{l}\text { Regresyon Modelin } \\
\text { Özeti }\end{array}$ & \multicolumn{3}{|c|}{$\mathrm{R}^{2}=.067 ;$ Adj. $\mathrm{R}^{2}=.061$} & $\begin{array}{l}\mathrm{R}^{2} \\
\mathrm{~F}=\end{array}$ & \multicolumn{3}{|c|}{$\mathrm{R}^{2}=.046 ;$ Adj. $\mathrm{R}^{2}=.040$} & \multicolumn{3}{|c|}{$\mathrm{R}^{2}=.105 ;$ Adj. $\mathrm{R}^{2}=.099$} \\
\hline $\begin{array}{l}\text { TDDÖ: Toksik Duyg } \\
\text { Tekduy: Tekrarlana } \\
\text { Bağkes: Bağlantıyı K } \\
\text { Bezduy: Bezdirici Dı }\end{array}$ & $\begin{array}{l}\text { eneyim } \\
\text { uygular } \\
\text { Duygu } \\
\text { lar }\end{array}$ & Ölçeği & & & & & & & & \\
\hline
\end{tabular}

Tablo 8'de verilen bulgular göre, iyimserliğin TDDÖ ve ilgili diğer boyutlarıyla kurulan regresyon modellerinin anlamlı olduğu görülmektedir ( $\mathrm{p}<.05)$. Buna göre bağımsız değişken olarak iyimserliğin TDDÖ $(\beta=-.298$; $\mathrm{p}<0.05)$, tekduy $(\beta=-.258 ; \mathrm{p}<0.05)$, bağkes $(\beta=-.213 ; \mathrm{p}<0.05)$ ve bezduy $(\beta=-.332 ; \mathrm{p}<0.05)$ bağıml değişkenlerini anlamlı ve negatif şsekilde etkilediği tespit edilmiştir. Bu bulgulardan hareketle $\mathrm{H} 4$ kabul edilmiştir.

Tablo 9.

Kötümserliğin Toksik Duygu Deneyimleri Üzerindeki Etkisine İlişkin Regresyon Testi Bulguları

\begin{tabular}{|c|c|c|c|c|c|c|c|c|c|}
\hline \multirow{2}{*}{$\begin{array}{l}\text { BAĞIMSIZ } \\
\text { DEĞİŞKNLER }\end{array}$} & \multicolumn{9}{|c|}{$\begin{array}{l}\text { BAĞIMLI DEĞİŞKEN } \\
\text { TDDÖ }\end{array}$} \\
\hline & \multirow{2}{*}{$\begin{array}{l}\beta \\
.598\end{array}$} & \multicolumn{2}{|c|}{ S.H. } & $p$ & \multicolumn{5}{|c|}{ Regresyon Modelin Özeti } \\
\hline \multirow[t]{3}{*}{ KÖTÜMSERLİK } & & .065 & & .000 & $\mathrm{R}^{2}=.3$ & Adj. $R^{2}$ & $4 ; F=9$ & $25 ; p=$ & \\
\hline & \multicolumn{3}{|c|}{ Tekduy } & \multicolumn{3}{|c|}{ Bağkes } & \multicolumn{2}{|c|}{ Bezduy } & \\
\hline & $\beta$ & S.H. & $p$ & $\beta$ & S.H. & $p$ & $\beta$ & S.H. & $p$ \\
\hline KÖTÜMSERLİK & .586 & .076 & .000 & .563 & .078 & .000 & .430 & .079 & .000 \\
\hline $\begin{array}{l}\text { Regresyon Modelin } \\
\text { Özeti }\end{array}$ & \multicolumn{3}{|c|}{$\begin{array}{l}\mathrm{R}^{2}=.343 ; \text { Adj. } \mathrm{R}^{2}=.339 \\
\mathrm{~F}=91.845 ; p=.000\end{array}$} & \multicolumn{3}{|c|}{$\begin{array}{l}\mathrm{R}^{2}=.317 ; \mathrm{Adj} . \mathrm{R}^{2}=.313 \\
\mathrm{~F}=81.768 ; p=.000\end{array}$} & \multicolumn{3}{|c|}{$\begin{array}{l}\mathrm{R}^{2}=.185 ; \text { Adj. } \mathrm{R}^{2}=.180 \\
\mathrm{~F}=39.949 ; p=.000\end{array}$} \\
\hline $\begin{array}{l}\text { TDDÖ: Toksik Duyg } \\
\text { Tekduy: Tekrarlanar } \\
\text { Bağkes: Bağlantıyı K } \\
\text { Bezduy: Bezdirici Du }\end{array}$ & $\begin{array}{l}\text { neyim } \\
\text { ygular } \\
\text { Duygn } \\
\text { ar }\end{array}$ & Ilçeğ $i$ & & & & & & & \\
\hline
\end{tabular}


Tablo 9'da verilen bulgulara göre kötümserliğin TDDÖ ve ilgili diğer boyutlarılya kurulan regresyon modellerinin anlamlı olduğu görülmektedir $(\mathrm{p}<.05)$. Bu modeller incelendiğinde ise kötümserliğin; TDDÖ $(\beta=.598 ; \mathrm{p}<0.05)$, tekduy $(\beta=.586 ; \mathrm{p}<0.05)$, bağkes $(\beta=.563 ; \mathrm{p}<0.05)$ ve bezduy $(\beta=.430 ; \mathrm{p}<0.05)$ bağıml değişkenlerini anlamlı ve olumlu şekilde etkilediği görülmektedir. Kötümserliğin en fazla TDDÖ değişkenini yordadığı görülmektedir. Bu bulgular neticesinde H5 kabul edilmiştir.

\section{Aracılık Testi Bulguları}

$\mathrm{Bu}$ araştırmada asıl cevabı aranan konu ise, Algılanan Sosyal Destek ve Toksik Duygu Durumları ilişkisinde iyimserlik/kötümserliğin aracılık rolünün olup olmadığıdır. Bu aracılık rolünü ortaya koyabilmek için mevcut veriler, Andrew F. Hayes tarafından geliştirilen ve SPSS paket programına sonradan eklenebilen PROCESS makrosu kullanılmıştır (Hayes 2013, s. 16). PROCESS makrosu önemli bir avantajı olarak tüm modelin ve aracı değişkenin dolaylı etkisini (aracılık etkisini) birlikte değerlendirip göstermesidir (Kuşluvan vd. 2016, s. 88). Bu makroda stabilitenin kontrol altında tutulabilmesi için bootstrap metodu uygulanmaktadır. Burada ifade edilen bootstrap güven aralığı ile anlamlılık değeri (significancy) için güven derecesinin üst (ULCI) ve alt (LLCI) değerleri ve yeniden örnekleme metodu belirlenmekte ve tercih edilmektedir. Güven aralığının anlamlı sayılabilmesi için her ikisinin de ya sıfırdan büyük ya da küçük olmalıdır. Diğer yandan yeniden örnekleme metodu ile az miktardaki örneklemi binlerce tekrarlayarak örneklemin temsil kabiliyetini kuvvetlendirmektedir (Hayes 2018, s. 95-97). Böylece az veri setlerinden anlamsız sonuçların önüne geçilmiş olmakta ve sağlıklı sonuçlara ulaşmayı sağlamaktadır (Arslan ve Yener 2015, s. 297).

$\mathrm{Bu}$ araştırmada aracı etkiyi sınamak amacıyla 178 örneklem üzerinden \%95 güven aralığında ve yanlılık hatasından arındırmak maksadıyla bootstrap yöntemi ile oluşturulan 1000'lik örneklem metodu kullanılarak aracılık etkisi modeli kurulmuştur. Bu aracı rol etkisi ise PROCESS makrosunun model 4'ü kullanılarak (Hayes 2013, s. 105-113) tespit edilmeye çalışllmıştır. Elde edilen bulgular da Tablo 10’da gösterilmiştir.

Tablo 10

Algılanan Sosyal Destek ve Toksik Duygu Durumları İlişkisinde İyimserlik/Kötümserliğin Aracılık Rolüne İlişkin Bulgular Tablosu

\begin{tabular}{|c|c|c|c|c|c|c|c|c|c|}
\hline \multirow{4}{*}{$\begin{array}{l}\text { İyimserliğin Aracı } \\
\text { Olduğu İlişki }\end{array}$} & \multirow{4}{*}{$\begin{array}{l}\text { Toplam } \\
\text { Etki }\end{array}$} & \multirow{4}{*}{$\begin{array}{l}\text { Doğrudan } \\
\text { Etki }\end{array}$} & \multirow{4}{*}{$\begin{array}{l}\text { Dolaylı } \\
\text { Etki }\end{array}$} & \multirow{4}{*}{$\begin{array}{l}\text { Doğrudan } \\
\text { Etkinin p } \\
\text { Değeri }\end{array}$} & \multirow{4}{*}{$\begin{array}{l}\text { Dolaylı Etkinin } \\
\text { Bootstrap } \\
\text { Güven Aralığı } \\
\text { LLCI/ULCI }\end{array}$} & \multicolumn{3}{|c|}{ Sobel Testi } & \multirow{4}{*}{$\begin{array}{l}\text { Aracı } \\
\text { Etki } \\
\text { Türü }\end{array}$} \\
\hline & & & & & & \multirow{3}{*}{ SE } & \multirow[t]{3}{*}{$\mathrm{Z}$} & \multirow{3}{*}{$\mathrm{p}$} & \\
\hline & & & & & & & & & \\
\hline & & & & & & & & & \\
\hline ASDÖ $\rightarrow$ Bezduy & -.2796 & -.1582 & -.1214 & .1106 & $-.2483 /-.0393$ & .0423 & -2.8723 & .0041 & Tam \\
\hline Aile $\rightarrow$ Bezduy & -.1651 & -.0699 & -.0952 & .3829 & $-.2049 /-.0341$ & .0336 & -2.8306 & .0046 & Tam \\
\hline Arkadaş $\rightarrow$ Tekduy & -.2796 & -.1582 & -.1214 & .1299 & $-.1693 /-.0083$ & .0423 & -2.8723 & .0041 & Tam \\
\hline Özel $\rightarrow$ Bezduy & -.2197 & -.1452 & -.0741 & .0022 & $-.1639 /-.0259$ & .0281 & -2.6521 & .0080 & Kismi \\
\hline \multicolumn{10}{|c|}{ Kötümserliğin Aracı Olduğu İlişki } \\
\hline Arkadaş $\rightarrow$ Tekduy & -.1960 & -.0760 & -.1200 & .3125 & $-.2322 /-.0365$ & .0535 & -2.2408 & .0250 & Tam \\
\hline \multicolumn{10}{|c|}{ ASDÖ: Algilanan Sosyal Destek Ölçeği } \\
\hline \multicolumn{10}{|c|}{ Tekduy: Tekrarlanan Duygular } \\
\hline Bezduy: Bezdirici Du & & & & & & & & & \\
\hline
\end{tabular}

Tablo 10'da gösterilen bulgular incelendiğinde ilk olarak, bağımsız değişkenler ile bağımlı değişkenlerin ilişkisinde iyimserlik boyutunun aracı etkisinin sonuçları görülmektedir. Buna göre iyimserlik değişkenin analize dâhil edilmesiyle ASDÖ'nün bezduy üzerindeki doğrudan etkisinin $(-.1582 ; p=.1106)$ anlamını kaybettiği tespit edilmiştir. ASDÖ’nün bezduy üzerindeki dolaylı etkisinin (-.1214)\%95 güven düzeyinde Bootstrap LLCI (-.2483) ve ULCI (-.0393) güven aralığının her ikisinin de negatif olduğu görülmektedir. Ayrıca 
Sobel testi $(\mathrm{Z}=-2.8723 ; \mathrm{p}<.05)$ sonucu da anlamlı olduğu saptanmıştır. Bu nedenle ASDÖ’nün bezduy üzerindeki etkisinde iyimserliğin tam aracılık rolü üstelendiği ifade edilebilir.

İyimserliğin dâhil edilmesiyle beraber aile faktörünün bezduy üzerindeki doğrudan etkisinin (-.0699; p=.3829) anlamsız hale geldiği görülmektedir. Sobel testi $(Z=-2.8306 ; p<.05)$ sonuçlarının anlamlı ve Bootstrap LLCI (.2049) ile ULCI (-.0341) güven aralığının her ikisinin de negatif olması nedeniyle iyimserlik değişkenin tam aracılık etkisinin anlamlı olduğu saptanmıştır.

Yine iyimserliğin aracı değişken olarak analize dâhil edildiğinde arkadaş boyutunun tekduy üzerindeki doğrudan etkisinin (-.1582; p=.1299) anlamlılığını yitirdiği görülmektedir. Bootstrap LLCI (-.1693) ve ULCI (-.0083) güven aralığının her ikisinin de negatif olduğu görülmekte olup, Sobel testi $(Z=-2.8723 ; p<.05)$ sonucunun anlamlı olması nedeniyle bağımsız ile bağımlı değişkenler arasındaki anlamlı ilişkide iyimserliğin tam aracılık rolü üstlendiği saptanmıştır.

Özel boyutunun bezduy ile ilişkisinde iyimserliğin aracılık etkisi incelendiğinde ise iyimserliğin aracı değişken olarak analize dâhil edilmesiyle özel boyutunun bezduy üzerindeki doğrudan etkisi $(-.1452 ; \mathrm{p}=.0022)$ ise anlamlılığını yitirmediği tespit edilmiştir. Sobel testi $(Z=-2.6521 ; \mathrm{p}<.0080)$ anlamlı ve Bootstrap LLCI (-.1639) ve ULCI (-.0259) güven aralığının her ikisinin de negatif olduğu görülmekte olup iyimserliğin bu değişkenler arasındaki ilişkide kısmı aracılık etkisinin olduğu ortaya konulmuştur.

Son olarak da kötümserlik değişkenin aracı rol olarak analize dâhil olduğu modeller denenmiştir. Ancak sadece bağımsız değişken olarak belirlenen arkadaş ve tekduy bağımlı değişkeni ilişkisinde aracı rol oynadığı saptanmıştır. Buna göre kötümserlik aracı değişken olarak modele dâhil edildiğinde arkadaş boyutunun tekduy üzerindeki doğrudan etkisinin (-.0760; $\mathrm{p}=.3125)$ anlamlılığını yitirdiği tespit edilmiştir. Sobel testi $(\mathrm{Z}=-2.2408$; $\mathrm{p}<.0250)$ ile elde edilen bulgulara göre bağımsız ile bağımlı değişkenler arasında dolaylı ilişkinin anlamlı olduğu görülmektedir. Bunun yanında Bootstrap LLCI (-.2322) ve ULCI (-.0365) güven aralığının her ikisinin de negatif olduğu görülmekte olup kötümserliğin bu iki değişken arasındaki ilişkide tam aracılık etkisinin olduğu tespit edilmiştir.

Her ne kadar boyutlar bağlamında anlamlı aracılık modelleri tespit edilmiş olsa da, ASDÖ'nün TDDÖ üzerindeki etkisinde iyimserlik ve kötümserliğin aracı etkisinin olmaması nedeniyle H6 reddedilmiştir.

\section{Tartışma ve Sonuç}

Dinamik bir çevrede faaliyet gösteren örgüt çalışanları, belirsizlik, baskı, karmaşa, kıskançlık ve iletişim aksaklıkları gibi nedenlerden dolayı zehirli örgütsel ortamlarda çalışmak durumda kalabilmektedirler. Zehirli havanın solunması sonucunda çalışanların, moralinin, örgüte olan güvenlerinin, performanslarının ve verimliliklerinin olumsuz etkileneceği bilinen bir gerçektir. Nitekim insanları duyguları zehirlendiğinde entelektüel yeteneklerini kullanamadıkları bilinmektedir. Bu gibi durumlarda çalışanlar, diğer arkadaşlarıyla bağ kurarak onlardan sosyal destek bekleyebilirler. Diğer çalışanlar da acı çeken arkadaşlarının nefes alabileceği bir ortam yaratarak onların rahatlayabilmesi için iş yüklerini hafifletmeleri gerekebilmektedir.

Zehirli ortamlarda, toksisitenin önlenebilmesi ya da düzeyinin hafifletilebilmesi için özellikle yöneticilere de büyük görevler düşmektedir. Çalışanların birbirlerine sağladıkları dışsal bir özelliğe sahip olan sosyal destek kadar içsel olan iyimserlik de önemli bir etkendir. Bunun yanında çalışanların kötümserlik duygu durumları da iş ortamlarının zehirli bir ortama dönüşmesine neden olabilmektedir. Bireysel nitelikleri ifade eden iyimserlik ve kötümserlik kavramları hem kalıtım hem de çevresel faktörlerden kaynaklı olabilmektedir. Kalıtımsal özellikler kötümserliği \%25 oranında açıklarken, geçmiş deneyimler, kötümser ebeveynlerin rol model teşkil etmesi ve sergiledikleri kötümser davranışların bireylerin kötümserlik düzeylerinde önemli rol oynamaktadır (Ben-Zur, 2003, s. 69; Eryılmaz, 2015, s. 390). 
Büyük örtük değişken olarak belirlenen ASDÖ, aile ve arkadaş faktörlerinin iyimserliği arttıran etkilerinin olduğu tespit edilmiştir. Yapılan diğer çalışmalar sonucunda sosyal desteğin bireyin günlük yaşam olaylarıyla ve stres etkeni ile başa çıkma ve uyum sağlama yeteneğini geliştirdiğini göstermektedir (Huang vd., 2008, s. 1796; Lindorff, 2001, s. 281). Sosyal desteğin kişinin sağlı̆̆ını, refahını ve geleceğe ilişkin iyimserliğini etkilediğini net bir şekilde belirlenmiştir (Barnett vd., 2018, s. 188). İyi oluş değişkenleri ile sosyal destek arasında pozitif yönde orta düzeyde, depresyon ve yalnızlı̆̆ın sosyal destek ile negatif yönde orta düzeyde ilişkili olduğu tespit edilmiş olup (Yalçın, 2015, s. 21) bu çalışmanın bulguları desteklenmiştir.

İyimserlik değişkeni toksik duygu durumlarını düşürücü etkiye sahip iken kötümserliğin ise beklendiği gibi arttırıcı etkisinin olduğu saptanmıştır. Youssef ve Luthans (2007, s. 780)'in yapmış olduğu çalışma sonucunda toksisite durumlarında iyimserlik ve umut devreye girerek kişinin kısa sürede toparlanmasını sağlamadığı ortaya çıkmıştır. İyimserlik düzeyleri yüksek olan çalışanların problem çözebilme kapasiteleri ve esnek düşünerek yaratıcı oldukları bilinmektedir (Peterson, 2000, s. 44). Diğer taraftan manidar şekilde büyük örtük değişkenlerden ASDÖ’nün TDDÖ üzerinde anlamlı bir etkisi saptanmamıştır. Ancak ASDÖ'nün özel boyutu, bezdirici duyguları azalttığı tespit edilmiştir. $\mathrm{Bu}$ durum, sosyal desteğin her zaman olumlu etkisinin olamayacağına bağlanmaktadır. Çünkü sosyal desteğin alıcı kişide yaratacağı reaksiyonun olumsuz ya da etkisiz olma durumu da ihtimal dâhilindedir (Gray, 2018, s. 3).

Genel olarak literatürde sosyal desteğin toksisiteyi azaltan etkisinden bahsedilmektedir. Çünkü toksik davranış veya durumlarla başa çıkabilmek adına çalışanlar sosyal desteğe başvurabilmektedir. $\mathrm{Bu}$ durumu iş arkadaşlarıyla ya da yöneticileriyle paylaşabilmektedirler. Sosyal desteğin düzeyi ne olursa olsun her zaman tükenmişlik ve stres gibi toksik iklimin düzeyini düşürerek iyimserliği arttırdığı ifade edilmektedir (Torun, 1995, s. 7). Bunun dışında sosyal destek alan kişilerin toksisiteyle mücadele etme kararı alarak direnebilir. Ayrıca iyimserliğini bozmadan işine odaklanabilir (Kasalak ve Aksu, 2016, s. 684). Çünkü bireyler bir tehdidi yönetmek için kullanılabilecek farklı başa çıkma seçeneklerini değerlendireceği ileri sürülmektedir. Aile arkadaş, özel kişiler veya içsel başa çıkma mekanizmalarını kullanabilmektedir. (Bowling ve Michel 2011, s. 310). Bunun sonucunda ise toksisitenin patolojik etkileri azaltılarak biyolojik ve ruhsal hastalığın da önüne geçmesi söz konusudur (Chien vd., 2000, s. 69-84).

Çalışmada, iyimserlik boyutu analiz modeline dâhil olduğunda bezdirici davranışların ASDÖ ve aile boyutuyla ile ilişkisinde tam ve özel boyutu ile kısmı aracılık etkisine sahipken arkadaş boyutu ile tekrar eden davranışların iliş̧isinde ise tam aracılık rolü üstlendiği saptanmıştır. Buradan hareketle tek başına sosyal desteğin toksisite ile mücadele etmede yeterli olmadığı söylenebilir. Aynı zamanda kişinin iyimser olması gerekmektedir. Yani bu iki bileşeninin bir araya gelmesi sonucunda bir sinerji yaratarak daha etkili sonuçların alınmasını sağlayabilir. Toksisite ile başa çıkmada, bir zorluk karşısında dayanıklılık düzeyinin ve çevresel desteklerin yeterli derecede olması gerekmektedir. Bu bileşenlerin birbirini desteklediği açıktır (Youssef ve Luthans, 2007, s. 779-780). Başarılı olmak için zorluklarla mücadele etmek ve çeşitli desteklerden faydalanmak gerekebilmektedir. İyimser açıklama tarzı ise bu direncin önemli bir anahtarı olduğu ifade edilmektedir. İyimser ve sosyal yönü güçlü bireyler başarısız olduklarında nedenini araştırmakta ve çözüm aramaktadır. Bu nedenle zor ve stresli bir işi yapmak üzere seçilecek adaylarda motivasyon ve güçlü sosyal ilişki yeteneğin yanında ayrıca iyimserlik de aranması konusunda görüşler bulunmaktadır (Türkmenoğlu, 2017, s. 122).

Çalışmada, kötümserlik boyutu analiz modeline dâhil edildiğinde arkadaşlık ile tekrar eden davranışlar ilişkisinde tam aracılık rolüne sahip olduğu tespit edilmiştir. Normalde arkadaşlık boyutu, tekrar eden duyguları yüksek oranda düşürürken kötümserliğin araya girmesiyle arkadaşlı̆̆ın etkisi gittikçe azalmıştır. İş arkadaşlarının, bireylerin toksisiteyle mücadelesinde önemli rol oynadığ ifade edilmektedir. Onlara önemli bazı davranışsal destek sağladıkları (Chiaburu ve Harrison, 2008, s. 1085) belirtilmiştir. Ancak her ne kadar kişi arkadaşlarına güvense, duygularını paylaşsa, sorunlarını dile getirse ve yardım alsa da kötümser bir yapıya sahip olduğunda bunların etkisi azalabilmektedir. 
Fredrickson (2009) olumsuz duygular, kişinin anlık düşüncelerini ve eylemlerini kısıtladığını ve olumlu duygular ise bireyin dikkatini, düşünmesini ve davranışsal repertuarlarını genişletme potansiyeline sahip olduğunu ortaya koymuştur (Hefferon ve Boniwell, 2014, s. 24; Çetin, 2017, s. 114; Carr, 2015, s. 25; Tugade vd., 2004, s. 1166). Olumlu duygular, güçlü bir büyüme ve değişim kaynağıdır. Bu kaynak birbirinden beslenen ve yukarı doğru bir spiral şeklinde yükseldiği ifade edilmektedir (Cohn vd., 2009, s. 372). Daha kapsayıcı ve aktif sosyal gruplar, daha esnek hedefler ve geniş zihniyet ürettiği görülmektedir. Bu nedenle sosyal grupların ve informal ilişkilerin geliştirilmesine imkân verilmelidir. Öyle ki bu çalışmada arkadaş desteğinin kötümserliği azalttığı saptanmıştır. Dolayısıyla örgüt içerisinde toksik duyguları etkin bir şekilde azaltmak ve eğer mümkünse, dikkat ve şefkat gibi yapıcı uygulamalarda bulunmak, örgütün toksik duyguların üretilmesi ve yayılması engellenebileceği ileri sürülmektedir (Chu, 2014, s. 960). Olumlu duyguların yayılmasının sağlanmasıyla çalışanların zamanla tükenme, izole edilme ve yabancılaşma sorunlarının önüne geçilebilir (Kasalak ve Aksu, 2016, s. 688). Böylelikle çalışanların toksisite ile mücadele noktasında başa çıma için kaynak ve strateji oluşturmalarına yardımcı olunmuş olacağı ileri sürülmektedir (Kiefer ve Barclay, 2012, s. 602). En nihayetinde insanların ailesinden, arkadaşlarından veya hayatlarındaki özel kişilerle sevinçlerini ve sorunlarını paylaşması, onlardan maddi ve maddi olmayan yardımlar alması ve güvenebileceği kişilerle yakın ilişkiler kurması iyimser düşünceyi tetikleyebileceği ileri sürülmektedir (Tugade vd., 2004, s. 1162).

$\mathrm{Bu}$ noktada yöneticilerin acı çeken çalışanları fark edebilmek için empati kurması gerekebilir. Toksinlerin atılması ya da tampon bölge inşa edilmesi için önemli görevler üstlenebilirler. Toksik bir duyguya maruz kalmış bir çalışana yapılacak en iyi müdahalelerden bir tanesi de ona serbest alan yaratmaktır. Çalışanın bir süre sonra kendi kendini toparladığı ifade edilmektedir. Bazen çalışanlara ailelerine zaman ayırmalarına izin verilmelidir. Toksik duyguyu yaşayan kimsenin bazen de farkında olmadan diğer çalışanları zehirlediği belirtilmektedir. Bu tür durumlarda örgütün müdahalesi gerekebilmektedir. Mağdur kişilerin, duygusal açıdan zor durumlarla başa çıksalar bile onları duygusal olarak sağlıklı tutan bir dizi tutum ve rutine erişmeleri gerekebilmektedir. Sürekli sağlık ve performansın anahtarı, insanların iyileşmesi için periyodik olarak dinlenme veya mola vermelerine izin veren alışkanlıklar ve ritüeller oluşturmalarını gerektirebilmektedir. Her gün toksinlere karşı savaşan çalışanlar kuruluştan yardım almaları sağlanmalı ve gerekli eğitimler düzenlenmelidir (Frost, 2004, s. 118-122).

\section{Kaynakça}

Akın, A. (2015). Öznel iyi olma. A. Akın ve Ü. Akın (Ed.), Psikolojide güncel kavramlar I: pozitif psikoloji (s. 6-10) içinde. Ankara: Nobel Akademik Yayınları.

Aksu, G., Eser, M. T. ve Güzeller, C. O. (2017). Açımlayıcı ve doğrulayıcı faktör analizi ile yapısal eşitlik modeli uygulamaları. Ankara: Detay Yayıncilık.

Arıc1, N. (2015). Pozitif dayanıklılık. A. Akın ve Ü. Akın (Ed.), Psikolojide güncel kavramlar I: pozitif psikoloji (s. 149-150) içinde. Ankara: Nobel Akademik.

Avey, J., Wernsing, T. ve Luthans, F. (2008). Can positive employees help positive organizational change? impact of psychological capital and emotions on relevant attitudes and behaviors. The Journal of Applied Behavioral Science, 44(1), 48-70. doi: 10.1177/0021886307311470

Barnett, M. D., Martin, K. J., ve Garza, C. J. (2018). Satisfaction with work-family balance mediates the relationship between workplace social support and depression among hospice nurses. Journal of Nursing Scholarship, 51(2), 187-194. doi:10.1111/jnu.12451

Bektaş, M. ve Erkal, P. (2015). Toxicity behaviors in organizations: Study of reliability and validity of toxic emotional experiences scale. Research. Journal of Business and Management, 2(4), 519-529. doi: 10.17261/Pressacademia.2015414060

Ben-Zur, H. (2003). Happy adolescents: The link between subjective well-being, internal resources, and parental factors. Journal of Youth and Adolescence, 32(2), 67-79. doi: 10.1023/A:1021864432505 
Bhanthumnavian, D. (2003). Perceived social support from supervisor and group members' psychological and situational characteristics as predictors of subordinate performance in thai work units. Human Resource Development Quarterly, 14(1), 79-97. doi: 10.1002/hrdq.1051

Bowling N.A. ve Michel J.S. (2011). Why do you treat mebadly? the role of attributions regarding the cause of abusein subordinates' responses to abusive supervision. Work and Stress, 25, 309-320. doi: $10.1080 / 02678373.2011 .634281$

Cameron, K. (2013). Pozitifliderlik olağanüstü bir performans için stratejiler. Tuğba Çekinirer (Çev.). İstanbul: Aritan Yayınevi.

Carr, A. (2015). Pozitif psikoloji. Ümit Şendilek (Çev.). İstanbul: Kaknüs Yayınlar.

Chiaburu, D. S. ve Harrison, D. A. (2008). Do peers make the place? conceptual synthesis and meta-analysis of coworker effects on perceptions, attitudes, OCBs, and performance. Journal of Applied Psychology, 93(5), 1082. doi: 10.1037/0021-9010.93.5.1082

Chien, S., H. Chang ve J. Schaller (2000). Perspectives of adolescents with visual impairments on social support from their parents. Journal of Visual Impairment and Blindness, 94(2), 69-84. doi: $10.1177 / 0145482$ X0009400202

Chu, L. C. (2014). Mediating toxic emotions in the workplace-the impact of abusive supervision. Journal of Nursing Management, 22(8), 953-963. doi: 10.1111/jonm.12071

Clara, I. P., Cox, B. J., Enns, M. W., Murray, L. T. ve Torqrudc, L. J. (2003). Confirmatory factor analysis of the multidimensional scale of perceived social support in clinically distressed and student samples. Journal of Personality Assessment, 81(3), 265-270. doi: 10.1207/S15327752JPA8103_09

Cohen, S. and T.A. Wills (1985). Stress, social support and buffering hypothesis. Psychological Bulletin, 98(2), 310-357. doi: 10.1037/0033-2909.98.2.310

Cohn, M. A., Fredrickson, B. L., Brown, S. L., Mikels, J. A., ve Conway, A. M. (2009). Happiness unpacked: positive emotions increase life satisfaction by building resilience. Emotion, 9(3), 361. Doi: $10.1037 / \mathrm{a} 0015952$

Collins, A. M., Hislop, D. ve Cartwright, S. (2016). Social support in the workplace between teleworkers, officebased colleagues and supervisors. New Technology, Work and Employment, 31(2), 161-175. doi: $10.1111 /$ ntwe. 12065

Çalışkan, H. ve Uzunkol, E. (2018). Ergenlerde iyimserlik-kötümserlik ölçeğinin geliştirilmesi: Geçerlilik ve güvenirlik çalışması. The Journal of Happiness \& Well-Being, 6(2), 78-95. Erişim adresi: https://toad.halileksi.net/sites/default/files/pdf/iyimserlik-kotumserlik-olcegi-toad.pdf

Çetin, F., (2017). Psikolojik sermaye. B. Akdemir (Ed.). İnsan kaynakları yönetiminde güncel yaklaşımlar içinde. İstanbul: Beta Yayınları.

Daalen, G. V., Willemsen, T. M. ve Sanders, K. (2006). Reducing work-family conflict through different sources of social support. Journal of Vocational Behavior, 69(3), 462-476. doi: 10.1016/j.jvb.2006.07.005

Eker, D., Arkar, H. ve Yaldız, H. (2001). Çok boyutlu algılanan sosyal destek ölçeği'nin gözden geçirilmiş formunun faktör yapısı, geçerlik ve güvenirliği. Türk Psikiyatri Dergisi, 12(1), 17-25. Erişim adresi: https://app.trdizin.gov.tr/publication/paper/detail/TVRVNU9ESXk

Eryılmaz, A. (2015). Sistem yaklaşımı açısından kötümserlik. Psikiyatride Güncel Yaklaşımlar, 7(4), 391-400. doi: 10.5455/cap.20150203014025

Fredrickson, B. L. (2001). The role of positive emotions in positive psychology: The broaden-and-build theory of positive emotions. American Psychologist, 56(3), 218-226. doi: 10.1037/0003-066X.56.3.218

Frost, P.J. (2004). Handling toxic emotions: New challenges for leaders and their organization. Organizational Dynamics, 33(2), 111-127. doi: 10.1016/j.orgdyn.2004.01.001 
Gray, C. E. (2018). You're not helping: Unhelpful workplace social support as a job stressor (Doctoral Dissertation), University of South Florida. Erişim adresi: https://scholarcommons.usf.edu/etd/7510

Gürbüz, S. ve Şahin, F. (2015). Sosyal bilimlerde araştırma yöntemleri. Ankara: Seçkin Yayıncılık.

Hayes, A.F. (2013). Introduction to Mediation, Moderation, and Conditional Process Analysis: A RegressionBased Approach. New York: Guilford Press. doi: 10.1111/jedm.12050

Hefferon, K. ve Boniwell, I., (2011). Pozitif psikoloji: kuram, araştırma ve uygulamalar, Tayfun Doğan (Çev.). Ankara: Nobel Yayınevi.

Heider, F. (1946). Attitudes and cognitive organization. The Journal of psychology, 21(1), 107-112. doi: $10.1080 / 00223980.1946 .9917275$

Huang, C. Y., Sousa, V. D., Tsai, C. C., ve Hwang, M. Y. (2008). Social support and adaptation of taiwanese adults with mental illness. Journal of Clinical Nursing, 17(13), 1795-1802. doi: 10.1111/j.13652702.2008.02310.x

İslamoğlu, A. H. ve Alnıaçık, Ü. (2014). Sosyal bilimlerde araştırma yöntemleri. İstanbul: Beta Yayınları.

Karacaoğlu, K. ve İnce, F. (2013). Pozitif örgütsel davranışın örgütsel sinizm üzerindeki etkileri: kayseri ilindeki imalat sanayi işletmelerinde bir uygulama. Süleyman Demirel Üniversitesi, İIBF Dergisi, 18(1), 181-201. Erişim adresi: http://eds.a.ebscohost.com/eds/pdfviewer/pdfviewer?vid=0\&sid=60b264e6-6e0a414ca3f9-9a825d9c2d92\%40sdc-v-sessmgr02

Karademas, E.C. (2006). Self-efficacy, social support and well-being: The mediating role of optimism. Personality and Individual Differences, 40, 1281-1290. doi.org/10.1016/j.paid.2005.10.019

Kasalak, G., ve Aksu, M. B. (2016). How do organizations intoxicate? faculty's perceptions on organizational toxicity at university. Hacettepe University Journal of Education, 31(4), 676-694. doi: 10.16986/HUJE.2016015696

Kirmeyer, S. ve Lin, T. (1987). Social support: Its relationship to observed communication with peers and superiors. Academy of Management Journal, 30(1), 138-151. doi.org/10.5465/255900

Kiefer T. ve Barclay L.J. (2012). Understanding the mediating role of toxic emotional experiences in the relationship between negative emotions and adverse outcomes. Journal of Occupational and Organizational Psychology, 85, 600-625. doi: 10.1111/j.2044-8325.2012.02055.x

Kocagöz, E. ve Dursun, Y. (2010). Algılanan davranışsal kontrol, Ajzen'in teorisinde nasıl konumlanır? Alternatif model analizleri. Karamanoğlu Mehmet Bey Üniversitesi Sosyal ve Ekonomik Araştırmalar Dergisi, 2, 139-152. Erişim adresi: https://dergipark.org.tr/en/pub/kmusekad/issue/10217/125597

Kusy M. ve Holloway E. (2010). Toxic workplace! managing toxic personalities and their systems of power. Brooklyn: John Wiley \& Sons Publishing. Erişim adresi: https://aura.antioch.edu/facbooks/15

Kuşluvan, S., Başoda, A. ve Kuşluvan, H. (2016). Konaklama işletmelerinde çalışanların müşteri odaklılığının işgören devrine etkisi: iş tatmininin aracılık rolü. Anatolia: Turizm Araştırmaları Dergisi, 27(1), 79-95. doi: 10.17123/atad.vol27iss10005

Lindorff, M. (2001). Are they lonely at the top? social relationships and social support among australian managers. Work \& Stress, 15(3), 274-282. doi: 10.1080/026783701110.1080/02678370110066599

Lim, J., Bogossian, F. ve Ahern, K. (2010). Stress and coping in australian nurses: a systematic Review. International Nursing Review, 57, 22-31. doi: 10.1111/j.1466-7657.2009.00765.x

Marcinkus, W., Whelan-Berry, K. S. ve Gordon, J. R. (2007). The relationship of social support to the workfamily balance and work outcomes of midlife women. Women in Management Review, 22(2), 86-111. doi: $10.1108 / 09649420710732060$

Norem, J. K. (2001). Defensive pessimism, optimism, and pessimism. E.C. Chang (Ed.), Optimism and Pessimism: Implications for Theory, Research, and Practice içinde (pp. 77-100). Washington, DC: American Psychological Association. doi.org/10.1037/10385-004 
Oksanen, T., Kouvonen, A., Vahtera, J., Virtanen, M. ve Kivimäki, M. (2010). Prospective study of workplace social capital and depression: Are vertical and horizontal components equally important?. Journal of Epidemiology \& Community Health, 64(8), 684-689. doi: 10.1136/jech.2008.086074

Papatya, G., Papatya, N. ve Hamşığlu, A. B. (2016). Girişimci yönlülük, iç-girişimcilik ve işletme performans ilişkisi: Türkiye tekstil sektörü işletmelerinde bir araştırma. Hacettepe Üniversitesi İktisadi ve İdari Bilimler Fakültesi Dergisi, 34(4), 19-48. Erişim adresi: http://eds.a.ebscohost.com/eds/pdfviewer/pdfviewer?vid=0\&sid=12f054c7-6b20-4da6-b744df6810c0cb38\%40sdc-v-sessmgr03

Parkinson, B. (2006). Ideas and realities of emotion. Newyork: Routledge Publishing. Erişim adresi: https://books.google.com.tr/books?id=cXPxFZysTTUC\&lpg=PP1\&ots=sUOwbAiITl\&dq=Ideas\%20a nd\%20realities\%20of\%20emotion\&lr\&hl=tr\&pg=PR5\#v=onepage\&q=Ideas\%20and\%20realities\%20o f\%20emotion\&f=false

Peterson, C. ve Bossio, L. M. (2001). Optimism and physical well-being. E.C. Chang (Ed.), Optimism and Pessimism: Implications for Theory, Research, and Practice içinde (pp.127-145). Washington, DC: American Psychological Association, doi: 10.1037/10385-006

Peterson, C. (2000). The Future of Optimism. American Psychologist, 55(1), 44-55. doi: 10.1037/10385-006

Polat, Ü. ve Kahraman, B. B. (2013). Yaşlı bireylerin sağlıklı yaşam biçimi davranışları ve algılanan sosyal destek arasındaki ilişki. Furat Tip Dergisi, 18(4), 213-218. Erişim adresi: http://www.firattipdergisi.com/pdf/pdf_FTD_855.pdf

Polatcı, S. (2015). Örgütsel ve sosyal destek algılarının yaşam tatmini üzerindeki etkisi: İş ve evlilik tatmininin aracilık rolü. Ekonomik ve Sosyal Araştırmalar Dergisi, 11(2), 25-44. Erişim adresi: https://dergipark.org.tr/en/pub/esad/issue/38966/456069

Pugliesi, K. ve Shook, S. L. (1998). Gender, ethnicity and network characteristics: Variation in social support resources, Sex Roles, 38(3-4), 215-238. Erişim adresi: https://link.springer.com/article/10.1023/A:1018733116398

Seligman, M.E.P. (2006). Learned optimism: How to change your mind and your life. New York: Vintage Books. Erişim adresi: https://cds.cern.ch/record/1141313

Shumaker, S. A. ve Brownell, A. (1984). Toward a theory of social support: Closing conceptual gaps. Journal of Social Issues, 40(4), 11-36. doi: 10.1111/j.1540-4560.1984.tb01105.x

Sönmezsoy, N. (2018). Akademisyenlerin algıladıkları sosyal destek ve iş doyumu arasındaki ilişki (Yayınlanmamış Yüksek Lisans Tezi). Maltepe Üniversitesi, İstanbul. Erişim adresi: https://tez.yok.gov.tr/UlusalTezMerkezi/tezSorguSonucYeni.jsp

Spector P.E. ve Fox S. (2002). An emotion-centered model of voluntary work behavior: Some parallels between counterproductivework behavior (CWB) and organisational citizenship behavior (OCB). Human Resource Management Review, 12, 269-292. doi: 10.1016/S1053-4822(02)00049-9

Stroebe, W. ve Stroebe, M. (1996). Social psychology handbook of basic principles, New York: Guilford Press. Erişim adresi: https://psycnet.apa.org/record/1996-98402-020

Tepper B.J., Carr J.C., Breaux D.M., Geider S., Hu C. ve Hua W.(2009). Abusive supervision, intentions to quit and employees' workplace deviance: A power/dependence analysis. Organiza-tional Behavior and Human Decision Processes, 109, 156-167. doi: 10.1016/j.obhdp.2009.03.004

Toor, S. ve Ofori, G. (2010). Positive psychological capital as a source of sustainable competitive advantage for organizations. Journal of Construction Engineering and Management, 136(3), 341-352. Erişim adresi: https://pdfs.semanticscholar.org/7e5a/a685fc1fa37c1c16c4bd4e0e153339aa85f2.pdf

Torun, A. (1995). Tükenmişlik, aile yapısı ve sosyal destek ilişkileri üzerine bir inceleme (Yayınlanmamış Doktora Tezi), Marmara Üniversitesi, İstanbul. Erişim adresi: https://tez.yok.gov.tr/UlusalTezMerkezi/tezSorguSonucYeni.jsp 
Tugade, M. M., Fredrickson, B. L. ve Feldman Barrett, L. (2004). Psychological resilience and positive emotional granularity: Examining the benefits of positive emotions on coping and health. Journal of Personality, 72(6), 1161-1190. doi: 10.1111/j.1467-6494.2004.00294.x

Türkmenoğlu, İ. (2017). Pozitif yönetim - iş yerinde keyifli ortam yaratmak. Ankara: Elma yayınevi.

Usta, F., (2015). Umut. A. Akın ve Ü. Akın (Ed.), Psikolojide Güncel kavramlar I: pozitif psikoloji içinde (s. 74-81). Ankara: Nobel Akademik.

Wei F. ve Si S. (2013). Tit for tat? abusive supervision and counterproductive work behaviors: The moderating effects of locus of control and perceived mobility. Asia Pacific Journal of Management, 30, 281-296.doi: 10.1007/s10490-011-9251-y

Yalçın, İ. (2015). İyi oluş ve sosyal destek arasındaki ilişkiler: Türkiye'de yapılmış çalışmaların meta analizi. Türk Psikiyatri Dergisi, 26(1), 21-32. doi: 10.5080/u7769

Youssef, C. M. ve Luthans, F.. (2007). Positive organizational behavior in the workplace: The impact of hope, optimism, and resiliency. Journal of Management, 33(5), 774-800. doi: 10.1177/0149206307305562

Zimet, G.D., Dahlem, N.W., Zimet, S.G. ve Farley, G.K. (1988). The multidimensional scale of perceived social support. Journal of Personality Assessment, 52, 30-41.doi: 10.1207/s15327752jpa5201_2 